ESRI

RESEARCH

SERIES

NUMBER 69

DECEMBER 2017

\section{ESTABLISHING IDENTITY OF NON-EU NATIONALS IN IRISH MIGRATION PROCESSES}

SAMANTHA ARNOLD, MARTINA BYRNE AND ANNE SHERIDAN

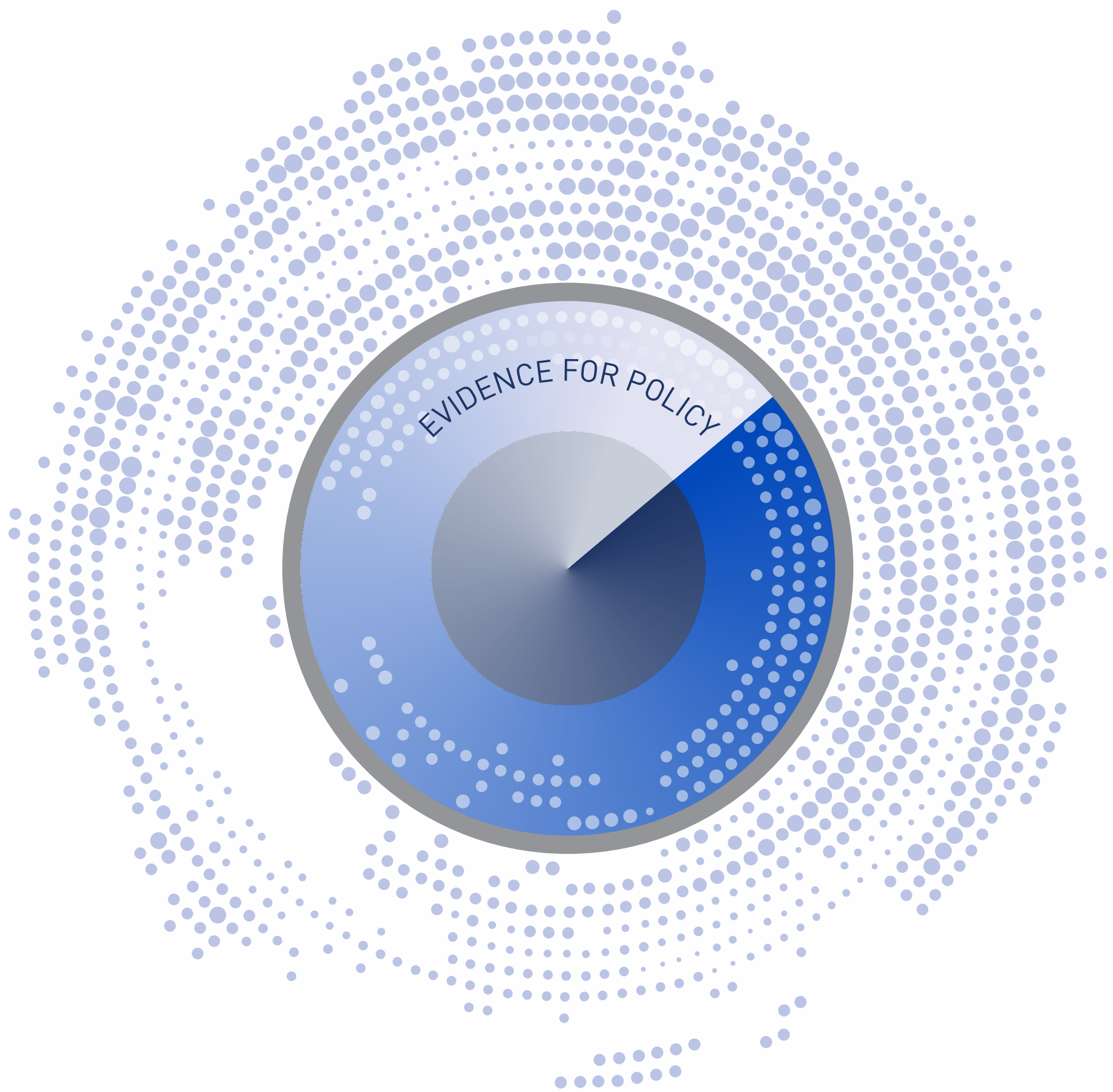




\title{
ESTABLISHING IDENTITY OF NON-EU NATIONALS IN IRISH MIGRATION PROCESSES
}

\author{
Samantha Arnold \\ Martina Byrne \\ Anne Sheridan
}

December 2017

\section{RESEARCH SERIES}

\section{NUMBER 69}

Study completed by the Irish National Contact Point of the European Migration Network (EMN) which is financially supported by the European Union and the Irish Department of Justice and Equality. The EMN has been established via Council Decision 2008/381/EC.

Available to download from www.emn.ie

(C) The Economic and Social Research Institute

Whitaker Square, Sir John Rogerson's Quay, Dublin 2

ISBN 978-0-7070-0446-4

DOI https://doi.org/10.26504/rs69

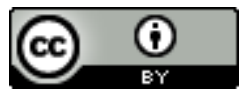

This Open Access work is licensed under a Creative Commons Attribution 4.0 International License, which permits unrestricted use, distribution, and reproduction in any medium, provided the original work is properly credited. 


\section{THE EUROPEAN MIGRATION NETWORK}

The aim of the European Migration Network (EMN) is to provide up-to-date, objective, reliable and comparable information on migration and asylum at Member State and EU levels with a view to supporting policymaking and informing the general public.

The Irish National Contact Point of the European Migration Network, EMN Ireland, sits within the Economic and Social Research Institute (ESRI).

\section{ABOUT THE ESRI}

The mission of the Economic and Social Research Institute is to advance evidencebased policymaking that supports economic sustainability and social progress in Ireland. ESRI researchers apply the highest standards of academic excellence to challenges facing policymakers, focusing on 12 areas of critical importance to 21st Century Ireland.

The Institute was founded in 1960 by a group of senior civil servants led by Dr T.K. Whitaker, who identified the need for independent and in-depth research analysis to provide a robust evidence base for policymaking in Ireland.

Since then, the Institute has remained committed to independent research and its work is free of any expressed ideology or political position. The Institute publishes all research reaching the appropriate academic standard, irrespective of its findings or who funds the research.

The quality of its research output is guaranteed by a rigorous peer review process. ESRI researchers are experts in their fields and are committed to producing work that meets the highest academic standards and practices.

The work of the Institute is disseminated widely in books, journal articles and reports. ESRI publications are available to download, free of charge, from its website. Additionally, ESRI staff communicate research findings at regular conferences and seminars.

The ESRI is a company limited by guarantee, answerable to its members and governed by a Council, comprising 14 members who represent a cross-section of ESRI members from academia, civil services, state agencies, businesses and civil society. The Institute receives an annual grant-in-aid from the Department of Public Expenditure and Reform to support the scientific and public interest elements of the Institute's activities; the grant accounted for an average of 30 per cent of the Institute's income over the lifetime of the last Research Strategy. The remaining funding comes from research programmes supported by government departments and agencies, public bodies and competitive research programmes.

Further information is available at www.esri.ie. 


\section{THE AUTHORS}

Samantha is a Post-Doctoral Research Fellow at the Irish National Contact Point of the European Migration Network (EMN), within the Economic and Social Research Institute (ESRI). Martina Byrne was a Research Assistant at the EMN. Anne Sheridan is Senior Policy Officer at the EMN.

\section{ACKNOWLEDGEMENTS}

In compiling this study valuable assistance was received from officials of INIS, the Garda Technical Bureau and the International Protection Office. Thanks are also due to representatives of the Immigrant Council of Ireland.

We also acknowledge the useful comments and suggestions received from our EMN intern, Conor Ryan, the EMN Ireland legal consultant and the referees.

Thanks are also due to Emma Quinn, Head of the Irish National Contact Point of the EMN for comments and guidance.

Finally, thanks are also due to our colleagues Elaine Byrne and Sarah Burns at the ESRI. We are grateful to everyone who shared their expertise with us for the purpose of writing this study.

\section{ABOUT THIS REPORT}

This European Migration Network study looks at the processes in place for establishing the identities of applicants for: short- and long-stay visas, residence and visitor permissions; international protection and permission to remain; and in relation to persons subject to a deportation order who have exhausted the asylum process. This study also looks at the process of establishing applicants' identities at the point of access to the national territory. The report consists of information gathered by way of a common template, primarily for an overview, EU-level synthesis report, Challenges and practices for establishing applicants' identity in the migration process.

This report has been accepted for publication by the Institute, which does not itself take institutional policy positions. All ESRI Research Series reports are peer reviewed prior to publication. The authors are solely responsible for the content and the views expressed and do not represent the position of the Economic and Social Research Institute, the Irish Naturalisation and Immigration Service, the Department of Justice and Equality, or the European Commission, Directorate-General Migration and Home Affairs. 



\section{TABLE OF CONTENTS}

EXECUTIVE SUMMARY.

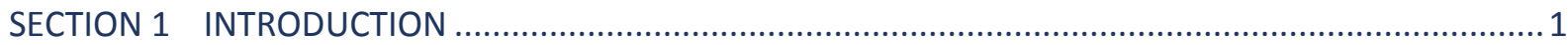

1.1 Objectives and background to the study ............................................ 1

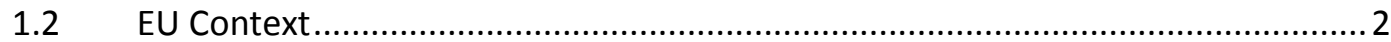

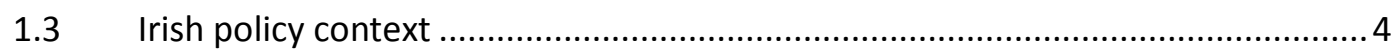

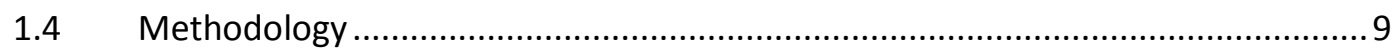

SECTION 2 ESTABLISHING IDENTITY OF NON-EEA NATIONALS IN MIGRATION PROCEDURES ..........13

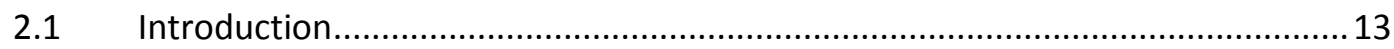

2.2 Organisation of responsible authorities.................................................. 13

2.3 Documentation requirements.............................................................. 15

2.4 Visa applications process: short- and long-stay visas.................................. 19

2.5 On arrival to Ireland: border control and the registration process...................23

2.6 International protection .................................................................... 28

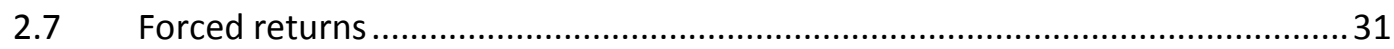

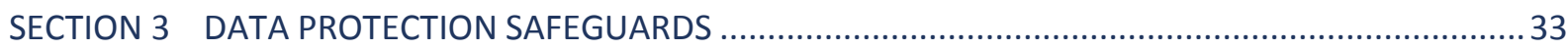

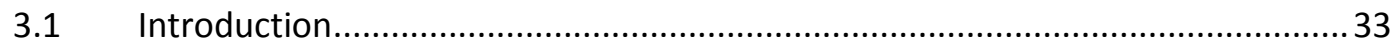

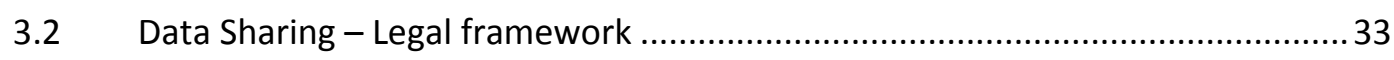

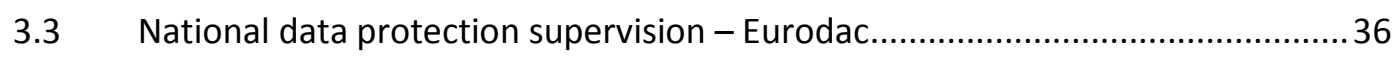

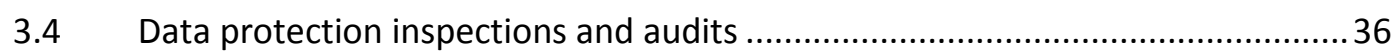

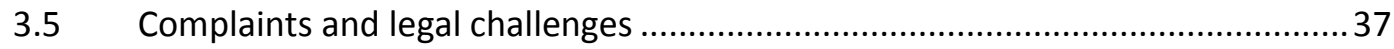

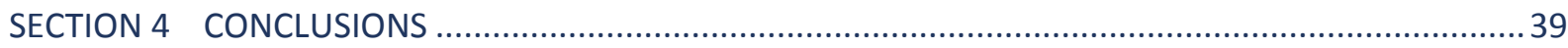

4.1 Documentation and biometric information ................................................ 40

L.2 Legislation and policy reform .................................................................. 40

4.3 Data sharing and protection............................................................... 41

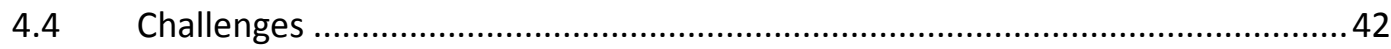




\section{LIST OF TABLES}

Table 1 Information and documentation to be furnished by non-EEA nationals at time of registration with GNIB/INIS

\section{LIST OF FIGURES}

Figure 1 Total number of visas applied for and refused in embassies or consulates in third countries, 2012-2016 ............................................................................................

Figure 2 First residence permits issued, by reason, per year, EU28, 2012-2015 ....................... 8

Figure 3 Total applications for international protection and all valid permits issued for protection reasons in Ireland, 2012-2016 8

Figure 4 Total number of forced returns of rejected applicants for international protection effected, 2012-2016...... 


\section{ABBREVIATIONS AND IRISH TERMS}

AFIS

AISIP

API

AVATS

BIVS

BMU

CJEU

CTA

Dáil

DPC

EDPS

EEA

Eircode

EMN

ESRI

EU

eu-LISA

Eurodac

Frontex

GNIB

GNIB-IS

GTB

ICAO

$\mathrm{ICl}$

iFADO
Automated Fingerprint Identification System

INIS case management database

Advance Passenger Information

Automated Visa Application Tracking System

British Irish Visa Scheme

Irish Naturalisation and Immigration Service Border Management Unit

Court of Justice of the European Union

Common Travel Area

Parliament, lower house

Data Protection Commissioner

European Data Protection Supervisor

European Economic Area

Irish postal code system

European Migration Network

Economic and Social Research Institute

European Union

European Agency for the operational management of large-scale IT systems in the area of freedom, security and justice

EU system for the comparison of fingerprints of asylum applicants to facilitate the application of the Dublin Regulation.

European Agency for the management of operational cooperation at the external borders of the Member States of the EU

Garda National Immigration Bureau

Garda National Immigration Bureau Information System

Garda Technical Bureau

International Civil Aviation Organisation

Immigrant Council of Ireland

Intranet False and Authentic Documents Online 
vi | Establishing identity of non-EU nationals in Irish migration processes

INIS

Irish Naturalisation and Immigration Service

IPO

International Protection Office

ORAC

Office of the Refugee Applications Commissioner

Nasc

Irish Immigrant Support Centre, Nasc

PNR

Passenger Name Record

PRADO

Public Register of Authentic travel and identity Documents Online

SIS II

Schengen Information System II

TCN

Third-Country National

UNHCR

Office of the United Nations High Commissioner for Refugees

VAC

Visa Application Centre

VIS

Visa Information System 


\section{EXECUTIVE SUMMARY}

Establishing the identity of non-EEA nationals ${ }^{1}$ entering the EU is often the first step in determining eligibility for visas, certain residence or visitor permissions and permissions associated with international protection statuses. Establishing identity is an EU-level policy priority as set out in both the European Agenda on Security (European Commission, 2015a) and the European Agenda on Migration (European Commission, 2015b).

No legal or overarching definition of 'identity' in the context of migration procedures exists in the majority of Member States. For the purposes of migration, identity is generally established by documents such as birth certificates, passports or other identity papers. Biometric identification refers to physical characteristics including fingerprints and digital facial images.

Any individual wishing to enter Ireland, whether visa required or not, is subject to immigration controls at ports of entry. All non-EEA (both visa required and nonvisa required) nationals require permission to enter Ireland upon arrival. ${ }^{2}$ Visa required non-EEA nationals must apply for a visa to travel to Ireland. However, an Irish visa is a form of pre-entry clearance to travel to a point of entry to the State only (Quinn, 2011). In almost all cases a passport or travel document is required in order for a non-EEA national to be issued a visa, to register in the State and to access the territory at the border. Protection applicants are not required to have a passport or travel document to access the asylum procedure.

This study looks at the processes in place for establishing the identities of applicants for: short- and long-stay visas; residence and visitor permissions; international protection and permission to remain; and in relation to persons subject to a deportation order who have exhausted the asylum process. This study also looks at the process of establishing applicants' identities at the point of access to the national territory.

While no data are available specifically on establishing identity within Irish migration processes, the following data provide a snapshot of the numbers of

Nationals from outside the European Economic Area comprised of the EU Member States, Iceland, Liechtenstein and Norway.

Citizens Information, 'Permission to enter Ireland', citizensinformation.ie; Immigration Act 2004, as amended, section 4. 
non-EEA nationals who went through the various immigration and returns procedures between 2012 and 2016.

- The total number of applications for visas increased by 40 per cent between $2012(74,562)$ and $2016(107,508)$. The total number of visas refused increased by 54 per cent between $2012(7,266)$ and 2016 $(11,154)$.

- In 2016, some 3,951 non-EU nationals were refused entry into the State (Department of Justice and Equality, 2017a). This is a 14 per cent increase from 3,451 in 2015 (Department of Justice and Equality, 2016b).

- The total number of first residence permits ${ }^{3}$ issued in Ireland has increased by 43 per cent from $2012(26,818)$ to $2015(38,433)$.

- The total number of asylum applications increased by 53 per cent from 2013 to 2014 (from 946 to 1,448). Applications increased again by 126 per cent between 2014 and 2015 (from 1,448 to 3,276). The number of applications has since decreased by 32 per cent from 2015 to 2016 (from $3,276$ to 2,244$)$.

- The number of valid permits ${ }^{4}$ issued for protection has increased annually from 2013 to 2015, increasing by 23 per cent from $2014(1,166)$ to 2015 $(1,430)$.

- The number of forced returns increased by 272 per cent from 2014 (53) to 2015 (197) and 86 per cent from 2015 to 2016 (367). The top five nationalities of persons returned on foot of a deportation order in 2015 were: Nigerian, Chinese, DR Congolese, Algerian and Iraqi.

\section{EU LEGISLATION AND POLICY}

Within the EU, establishing the identity of persons in legal migration channels such as short- and long-stay visas and residence permits is partially governed by law and policy at EU level. The EU Visa Code (Regulation (EC) No. 810/2009) sets out the procedures for issuing short-stay visas through Schengen states. Authorities in the relevant states must verify the admissibility of the application, which includes checking the identity of the visa holder and their documents. Article 5(2) of the Family Reunification Directive 2003/86/EC requires certified copies of the family member(s)' travel documents for applications for family reunification. 
Article 4(2) of the Recast Qualification Directive 2011/95/EU places an obligation on Member States to assess the identity of asylum applicants. Article 13 of the Recast Asylum Procedures Directive 2013/32/EU requires applicants to cooperate with the relevant authorities concerning the establishment of their identity. The Dublin III Regulation (EU) No. 604/2013 establishes the process for determining the Member State responsible for processing an asylum application. The Dublin III Regulation is complemented by the Eurodac Regulation (EU) No. $603 / 2013$ which provides for an EU asylum fingerprint database in order to establish the identity of applicants for international protection and of persons apprehended crossing the external EU border irregularly.

The Return Handbook (European Commission, 2015c) notes that persons subject to a returns decision may be detained subject to Article 15 of the Return Directive $2008 / 115 / E C$ if they lack documentation or if they do not co-operate with the competent authorities in the process of establishing the person's identity.

\section{IRISH LEGISLATION AND POLICY}

The establishment of the identities of non-EEA nationals in the context of migration procedures in Ireland is largely governed by national law and policy. Ireland did not exercise its right to opt-in to the Family Reunification Directive, the Recast Qualification Directive, Recast Procedures Directive or the Return Directive.

Identity, in the context of legal migration (short- and long-stay visas and residence permissions), is governed by the Immigration Act 2004, as amended. Identity in the context of international protection (asylum) is governed by the International Protection Act 2015. Ireland also participates in the Dublin Regulation and Eurodac Regulation.

Ireland does not participate in the border related aspects of the Schengen acquis and, as such, national authorities do not currently have access to VIS or SIS II. ${ }^{5}$ Ireland has requested to participate in certain aspects of the Schengen acquis via Council Decision 2002/192/EC, and will, subject to Schengen evaluation, participate in certain horizontal aspects including police co-operation provisions and SIS II. As Ireland has exercised its right to opt-in to the Dublin and Eurodac Regulations, this study examined data protection safeguards around data sharing

The VIS system allows for the exchange of visa data on short-stay visas between Schengen states and provides biometric matching for identification and verification purposes (Regulation (EC) No 767/2008). The SIS allows the exchange of information on persons who may have been involved in a serious crime between national authorities to assist in managing the common travel area. Capital funding of $€ 4$ million was announced in 2016 to allow Ireland to advance its SIS II project (Department of Justice and Equality, 2016a). 
and supervisory arrangements for the use of Eurodac. There are also national databases which complement procedures in respect of establishing and verifying the identities of non-EEA nationals.

\section{CO-OPERATION AND DATA SHARING}

There is a balance to be struck between the legitimate interest of controlling migration regarding establishing the identity of non-EEA nationals via data sharing or holding data in large databases, and the privacy rights of the individual also enshrined in EU law. This is achieved in Ireland by the provisions of the Data Protection Acts 1988 and 2003, which apply to all processing of personal data in the migration context. Ireland introduced new regulations in 2016, which provide a legal basis under data protection law for Irish carriers to provide Advance Passenger Information (API) to the UK for passengers entering the UK from Ireland. From autumn 2017, the Irish immigration authorities will also begin to systematically collect and analyse API data from carriers on inbound flights from outside the EU. ${ }^{6}$ Ireland is also implementing the EU Directive (2016/681) on Passenger Name Records (PNR) and, in time, both API and PNR data will be screened in the same Passenger Information Unit (PIU).

Ireland and the United Kingdom co-operate closely on jointly securing the external borders of the Common Travel Area (CTA). The British-Irish Visa Scheme (BIVS) was commenced in autumn 2014; it allows for travel to and around the CTA on a single visa. Visa data are shared for the purpose of the implementation of the Irish Short Stay Visa Waiver Programme and the British-Irish Visa Scheme. The implications of Brexit on these arrangements are unknown.

\section{IRISH INSTITUTIONAL FRAMEWORK AND PROCESSES}

There is no central competence centre for issues related to identification/identity verification of non-EEA nationals in Ireland; as a result a number of bodies are involved. The Visa Division of the Irish Naturalisation and Immigration Service (INIS) is responsible for verifying the identity of visa applicants in co-operation with other national authorities, such as the Garda National Immigration Bureau (GNIB) and the Garda Technical Bureau (GTB).

The INIS Border Management Unit (BMU) in co-operation with other national authorities, such as the Garda National Immigration Bureau (GNIB) and the Garda Technical Bureau (GTB), is responsible for front-line identity checks at Irish ports. 
The International Protection Office (IPO) has responsibility for making recommendations to the Minister as to whether applicants for international protection should be granted protection status. Credibility assessments are an essential part of the process and, within that, establishing nationality/identity to a certain extent (see more information below).

Officers of the INIS Registration Office and GNIB in Garda Districts outside Dublin are responsible for verifying the identity of non-EEA nationals upon registration once in the country.

The GTB may examine documents, e.g. travel documents, marriage licences, birth and death certificates, etc., on receipt of a request from another body (e.g. IPO or Visa Division). The GTB also takes and stores fingerprints where required.

The Repatriation Division of INIS is responsible for establishing the nationality of non-EEA nationals who are the subject of a deportation order. This is done through contact with embassies.

\section{KEY CHALLENGES}

Public and political debate relating to identity in the context of migration and its connection to security issues and border control has emerged in Ireland in recent years. These debates centre on measures to improve border controls and counter illegal immigration and security-related mechanisms such as Interpol checks. Additionally there has been media coverage related to challenges and practices regarding establishing identity including issues related to the deportation of those whose applications for asylum have failed; the presentation of false documents; terrorism; and the smuggling of immigrants into the country.

Establishing identity is considered an issue within the framework for all migration procedures but is particularly challenging in the context of international protection applicants many of whom do not present with identification, and in returns procedures for failed asylum seekers (European Migration Network, 2013). In Ireland, the IPO does not seek to establish identity; rather it is seen as part of the process of establishing the overall credibility of the applicant's claim.

Establishing identity is also commonly identified as challenging in the context of 'rejected asylum seekers' subject to a deportation order. In order to effect a deportation order, the nationality of the person, if not the identity, must be established, often in the absence of identity documentation. The process of seeking documents for return is resource intensive. 
Establishing identity in the context of visa applications is challenging where, for example Ireland has no embassy; there are issues with the issuance, translation or validity of supporting or breeder documents; passports are not machinereadable but hand written, making them easier to forge; or when a country is moving from one form/style of identity documentation to another. ${ }^{7}$

INIS Registration Office noted that establishing identity is an issue/challenge in the context of residence permits for family, study, and remunerated activities, where the applicant has a non-machine readable/non-electronic passport and therefore cannot be checked instantaneously against Interpol's Lost and Stolen Passport database via GNIB.

The number of passports seized for examination by the Garda Technical Bureau decreased in each year from 2014 to 2016. Some 104 passports and 52 identity cards were deemed invalid in 2016. In 2016, identity documents from Nigeria, Somalia, Pakistan and Ghana were most frequently seized for examination. 


\section{SECTION 1}

\section{Introduction}

\subsection{OBJECTIVES AND BACKGROUND TO THE STUDY}

Establishing the identity of non-EEA nationals ${ }^{8}$ entering the EU is often the first step in determining eligibility for visas, certain residency or visitor permissions and permissions associated with international protection statuses. Establishing identity is an EU-level policy priority as set out in both the European Agenda on Security (European Commission, 2015a) and the European Agenda on Migration (European Commission, 2015b).

No legal or overarching definition of 'identity' in the context of migration procedures exists in the majority of Member States. Belgium however has a legal definition of the term 'identified foreigner'. It is defined as a person who is in possession of a valid travel document, passport or identity document or a person who belongs to a category for whom the country of origin or the Belgian minister could issue a laissez-passer (European Migration Network, 2017).

This report is part of an EU-wide study on establishing identity in the migration process. Establishing identity is considered to be a challenge by State authorities across the EU (European Migration Network, 2017). Establishing identity is particularly challenging in the context of international protection. Most country reports highlighted the fact that the majority of applicants for international protection did not provide an official travel or identity document (European Migration Network, 2017). The challenges posed by applicants for international protection in respect of their identity have been the topic of recent EU-level discourse due to the surge in the number of asylum applications made in Europe in recent years, but in particular in 2014 and 2015.

Establishing identity is also commonly regarded as challenging in the context of 'rejected asylum seekers' subject to a deportation order. In order to effect a deportation order the nationality of the person, if not the identity, must be established, often in the absence of identity documentation. This process often involves engagement with third-country embassies (Sheridan, 2017). 
Firstly, this study looks at identification procedures and systems (e.g. biometric systems) which seek to identify an unknown person, thus answering the question: 'Who is this person?' Secondly, this study examines the identity verification procedures and systems which aim to answer the question: 'Is this person who they say they are?' (European Migration Network, 2017).

This study looks at the processes in place for establishing the identities of applicants for: short- and long-stay visas, residence and visitor permissions, international protection and permission to remain, and in relation to persons subject to a deportation order who have exhausted the asylum process. This study also looks at the process of establishing applicants' identities at the point of access to the national territory.

Section 2 provides an overview of the different procedures involved in establishing the identity of non-EEA nationals in the various processes. Section 2 also outlines the different bodies that are responsible for establishing identity and the databases that they access and use to store and share identity-related information. Challenges, including those mentioned above, are also discussed.

Section 3 outlines the legislative underpinning for data sharing necessary to ensure compliance with data protection legislation as it relates to establishing the identity of non-EEA nationals. It also examines the data protection supervisory arrangements for Eurodac, as well as complaints and legal challenges.

Key findings from the study are reviewed in Section 4.

\subsection{EU CONTEXT}

Border management is a priority area in the European Agenda on Migration, which was published in May 2015 (European Commission, 2015b). The Agenda explores risk trends, smart borders, and how to make better use of IT systems and technologies already in operation, such as Eurodac, the Visa Information System (VIS) and the Schengen Information System (SIS). Eurodac is a shared database which stores the fingerprints of international protection applicants and irregular migrants (Regulation (EU) No. 603/2013). It also allows Member States' law enforcement authorities and Europol to compare fingerprints linked to criminal investigations. The Eurodac Regulation entered into effect for Member States from 20 July 2015. The VIS system allows for the exchange of visa data on short-stay visas between Schengen ${ }^{9}$ States and provides biometric matching for 
identification and verification purposes (Regulation (EC) 767/2008). The VIS has also been rolled out to embassies and consulates in third countries. ${ }^{10}$ Ireland does not have access to VIS which is a feature of Schengen border cooperation. Ireland exercised its right to opt-in ${ }^{11}$ to the Eurodac Regulations, most recently Regulation (EU) 603/2013. ${ }^{12}$ The SIS allows the exchange of information on persons who may have been involved in a serious crime between national authorities to assist in managing the common travel area. Ireland lies outside the Schengen zone and as such does not fully participate in SIS. ${ }^{13}$

The EU agency, eu-LISA, is responsible for the management of all three systems. ${ }^{14}$ In April 2016 the European Commission (2016) published a Communication on 'Stronger and Smarter Information Systems for Borders and Security', building on the recommendations in the seventh Commission's Security Union Report (European Commission, 2017), one objective of which is to improve existing information systems.

The European Agenda on Security was published in April 2015. It outlines joint priority areas which support the EU's efforts to ensure that the block remains safe, where people can live freely and without internal borders (European Commission, 2015a). While border security is not a standalone priority area in the Agenda, it falls under a number of other priorities, including, for example bringing 'together all internal and external dimensions of security' (European Commission, 2015a: p. 4) to strengthen the SIS, now SIS II. ${ }^{15}$

\subsubsection{EU legal context}

Within the EU, establishing the identity of persons in legal migration channels such as short- and long-stay visas and residence permits is partially governed by law and policy at EU level. The following legal instruments and measures are relevant to the current study.

There is an obligation on applicants in legal migration channels to establish their identity by presenting a valid travel document. Verification of the validity of the travel document governs access to a given territory as a border check. The competent authorities are then responsible for verifying the authenticity of the document presented in the context of the various legal migration procedures.

\footnotetext{
Completed November 2015.

As provided for under Article 4 of Protocol 21 annexed to the TEU and TFEU.

Motion to approve the Regulation was passed in Dáil Éireann on 3 July 2014. www.oireachtasdebates.oireachtas.ie. See 'Schengen Information System', ec.europa.eu.

eu-LISA, 'Core activities', www.eulisa.europa.eu.

SIS II is the second generation of the SIS. It entered into operation 9 April 2013.
} 
(European Migration Network, 2017). Pursuant to Article 8 of the Schengen Borders Code Regulation (EU) 2016/399, the SIS II system is consulted at the border to check for matches in relation to entry bans, other SIS alerts and any necessary action to be taken.

Regulation (EC) No 810/2009, or the Visa Code, sets out the procedures for issuing short-stay visas throughout Schengen states. Authorities in the relevant states must verify the admissibility of the application, which includes checking the identity of the visa holder and their documents. A file must then be created in the VIS.

Article 5(2) of the Family Reunification Directive 2003/86/EC requires certified copies of family member(s)' travel documents to accompany applications for family reunification.

Article 4(2) of the Recast Qualification Directive 2011/95/EU places an obligation on Member States to assess the identity of the asylum applicant. Article 13 of the Recast Asylum Procedures Directive 2013/32/EU requires applicants to cooperate with the relevant authorities concerning the establishment of their identity.

The Dublin III Regulation (EU) 604/2013 establishes the process for determining the Member State responsible for processing an asylum application. In general the Member State responsible for examining the asylum application is the Member State in which the applicant first lodged their application. The Eurodac Regulation 603/2013 established an EU asylum fingerprint database. This database serves two main functions. It assists in establishing the identity of applicants. It also facilitates the application of the Dublin III Regulation. The Eurodac database complements the Regulation in that fingerprint evidence is used to indicate in which EU Member State the applicant first arrived.

Article 15 of the Return Directive 2008/115/EC establishes the grounds for detention of non-EEA nationals. The Return Handbook (European Commission, 2015c) notes that persons subject to a returns decision may be detained if they lack documentation or if they do not co-operate with the competent authorities in the process of establishing the person's identity.

\subsection{IRISH POLICY CONTEXT}

While Ireland did not exercise its right to opt-in to the Family Reunification Directive, the Recast Qualification Directive, Recast Procedures Directive or the 
Return Directive, Ireland does participate in the Dublin Regulation and Eurodac Regulation. This means that the establishment of the identities of non-EEA nationals in the context of migration procedures in Ireland is largely governed by national law and policy. Identity in the context of legal migration (short- and longstay visas and residence permissions) is governed by the Immigration Act 2004, as amended. Identity in the context of international protection is governed by the International Protection Act 2015 (see Section 2.6).

Ireland lies outside the Schengen zone and, as such, national authorities do not have access to SIS II or VIS. Ireland does not participate in the border related aspects of the Schengen acquis. However Ireland has requested to participate in certain aspects of the Schengen acquis via Council Decision 2002/192/EC, and will, subject to Schengen evaluation, participate in certain horizontal aspects including police co-operation provisions and SIS II. In December 2015, the Minister for Justice and Equality announced that she had secured additional capital funding of $€ 4$ million in 2016 to allow Ireland to advance its national SIS II project (Department of Justice and Equality, 2016a).

Irish law and policy governs the process of establishing the identities of non-EEA nationals (see Section 2). There are a number of national databases which also complement authorities' procedures in respect of establishing and verifying the identities of non-EEA nationals (see Sections 2 and 3).

Debates relating to identity in the context of migration, and its connection to security issues and border control, have recently emerged in Ireland. Concerns have been raised in parliament regarding national security following terror attacks in Europe, including concerns related to:

- $\quad$ intelligence sharing; ${ }^{16}$

- deportation orders; ${ }^{17}$

- $\quad$ progressing access to $\mathrm{SIS} ;{ }^{18}$

- mechanisms for the exchange of fingerprint and DNA data; ${ }^{19}$

- $\quad$ security on airbridges; ${ }^{20}$

- measures to improve border controls and counter illegal immigration threats and security-related mechanisms such as Interpol checks;

- Advance Passenger Information (API); and

\footnotetext{
Parliamentary Question 24 November 2015 [41378/15], oireachtasdebates.oireachtas.ie. Parliamentary Question 16 September 2016 [24371/16], oireachtasdebates.oireachtas.ie. Parliamentary Question 23 May 2017 [24337/17], oireachtasdebates.oireachtas.ie. Ibid. (Interview INIS (BMU), June 2017).
} 
- $\quad$ Passenger Name Records (PNR) (Department of Justice and Equality, 2017b; INIS, 2017).

Additionally there has been media coverage related to challenges and practices regarding establishing immigrant identity including issues related to: failed asylum seekers (Brady, 2012); false identities (Brady, 2015); terrorism (Brady, 2016; Department of Justice and Equality, 2017b; O'Driscoll et. al., 2017; Sheehan, 2017; Lally, 2017; Woulfe, 2017); smuggling of immigrants (Griffin, 2017); and false documents (Primetime, 2017; Phelan, 2017a; Phelan, 2017b; Phelan, 2017c).

\subsubsection{Overview of the main trends}

This section presents data on visa applications, residence permits issued, asylum applications and deportation orders in Ireland. All four categories fall within the scope of this study. The purpose of this section is to give a sense of the scale of the processes covered in the study.

\subsubsection{Visas}

Figure 1 shows that the total number of visas applied for in embassies and consulates in third countries has increased steadily during the study period (20122016). Likewise Figure 1 shows that the number of visas refused has also steadily increased. The total number of applications for visas increased by 40 per cent between $2012(74,562)$ and $2016(107,508)$. The total number of visas refused increased by 54 per cent between $2012(7,266)$ and $2016(11,154)$. The Irish Naturalisation and Immigration Service (INIS) Visa Division noted that while false, counterfeit and forged documents are detected, related data are not maintained or currently capable of being extracted electronically. ${ }^{21}$ 
FIGURE 1 TOTAL NUMBER OF VISAS APPLIED FOR AND REFUSED IN EMBASSIES OR CONSULATES IN THIRD COUNTRIES, 2012-2016

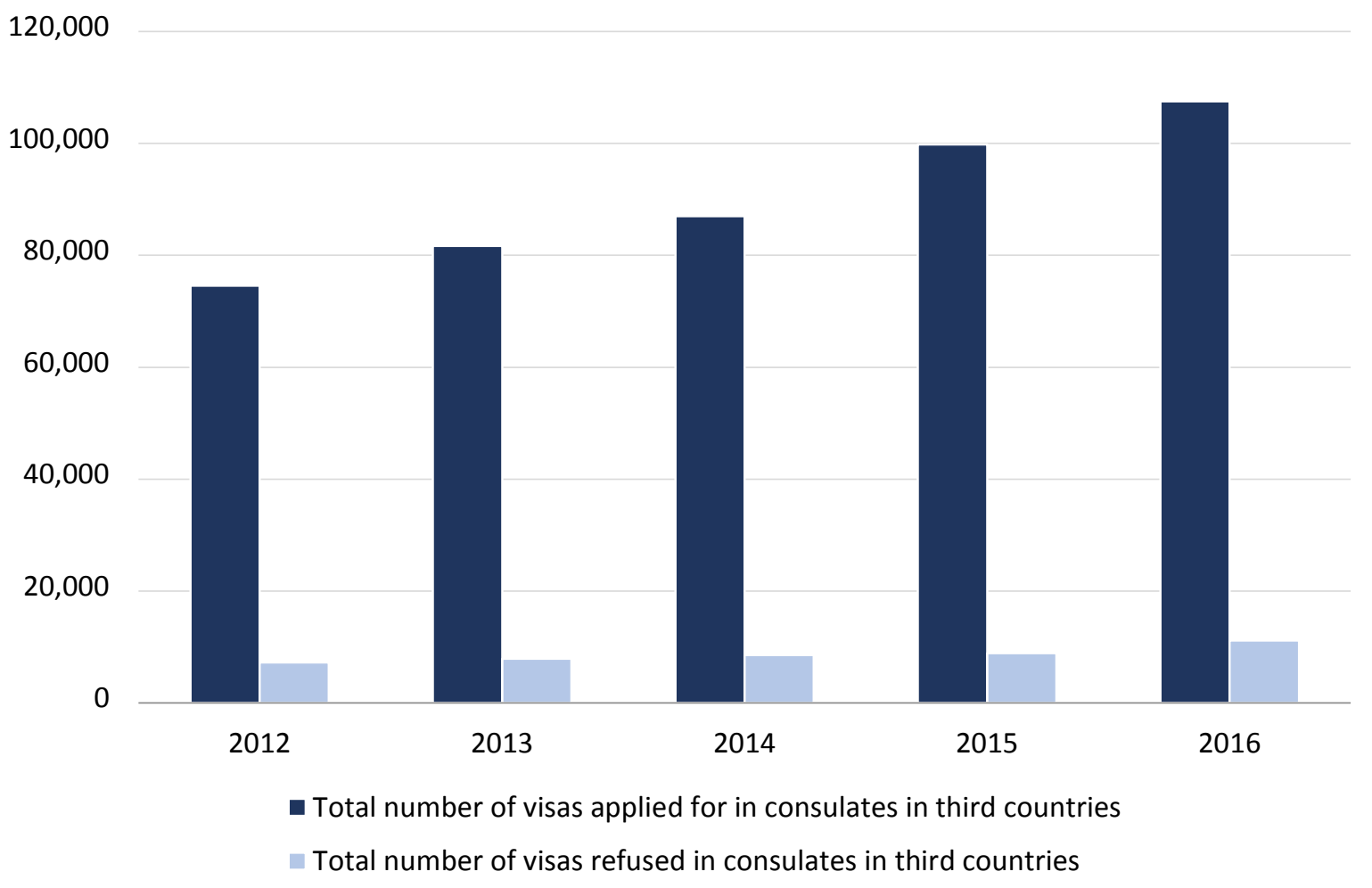

Source: Data received from INIS, 2017.

\subsubsection{Residence permits}

All non-EU persons who seek to reside in Ireland, for any reason, including those persons who arrive with a visa, must obtain a residence permit. In 2016 some 3,951 non-EU nationals were refused entry into the State (Department of Justice and Equality, 2017a). This is a 14 per cent increase from 3,451 in 2015 (Department of Justice and Equality, 2016b). The data presented below refer to first residence permits issued ${ }^{22}$ in Ireland from 2012 to 2015. Section 2 also looks at the process of establishing identity for persons applying for residence permits. This section provides some data on the number of persons issued residence permits in Ireland from 2012 to 2015 (2016 data were not available at time of going to print).

Figure 2 shows that the total number of first residence permits issued in Ireland has increased by 43 per cent from $2012(26,818)$ to 2015 (38,433). First permits issued for family, remunerated activities and other reasons have all increased annually from 2012 to 2015. First permits issued for education reasons increased annually from 2012 to 2014 and decreased slightly (7 per cent) from 2014 $(23,730)$ to $2015(22,075)$.

22 Permits issued excluding renewals. Eurostat [migr_resfas]. 


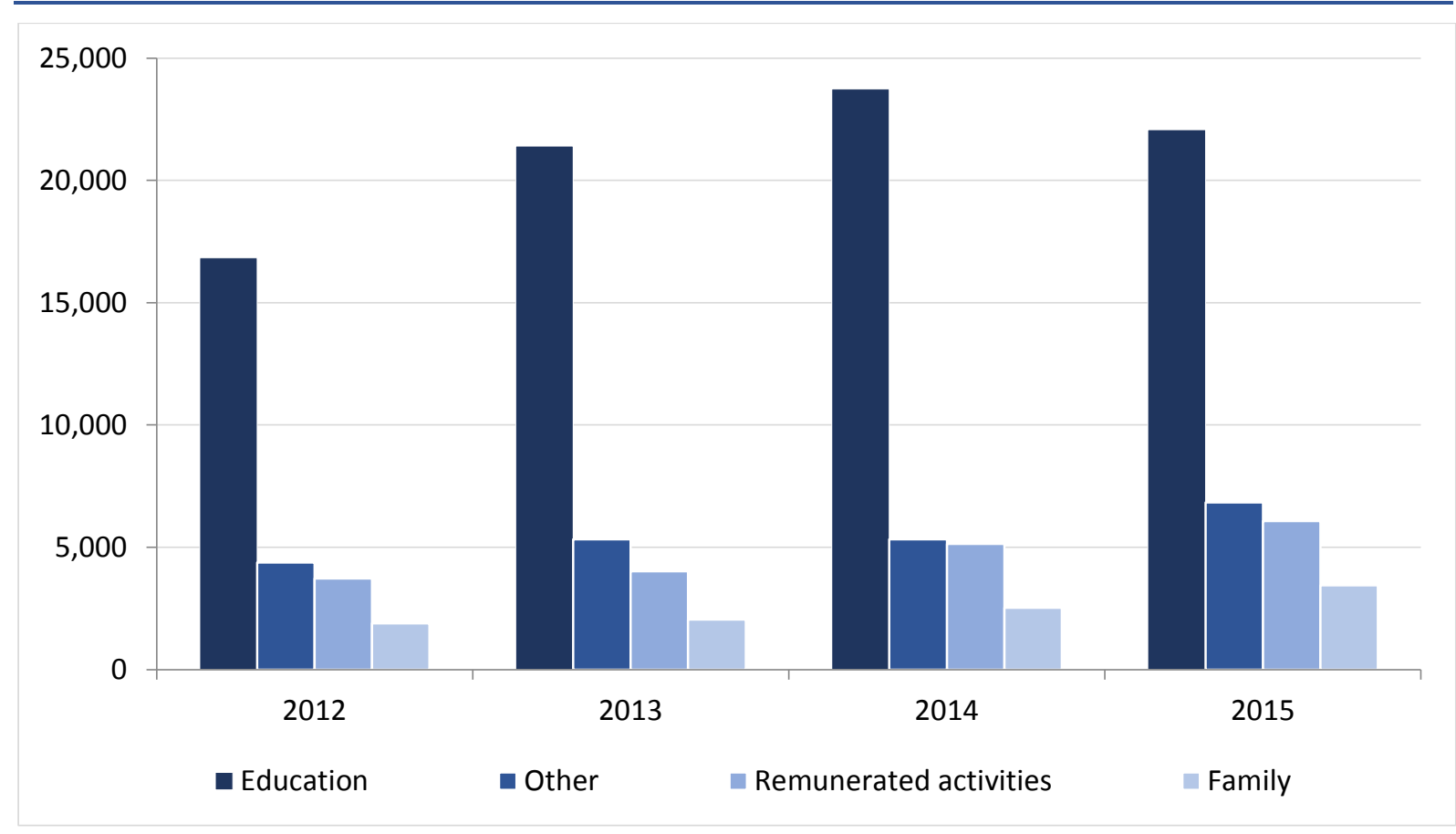

Source: $\quad$ Eurostat [migr_resfas].

\subsubsection{Asylum applications}

Figure 3 shows that the total number of asylum applications increased by 53 per cent from 2013 to 2014 (from 946 to 1,448). Applications increased again by 126 per cent from 2014 to 2015 (from 1,448 to 3,276). The number of applications has since decreased by 32 per cent from 2015 to 2016 (from 3,276 to 2,244).

FIGURE 3 TOTAL APPLICATIONS FOR INTERNATIONAL PROTECTION AND ALL VALID PERMITS ISSUED FOR PROTECTION REASONS IN IRELAND, 2012-2016

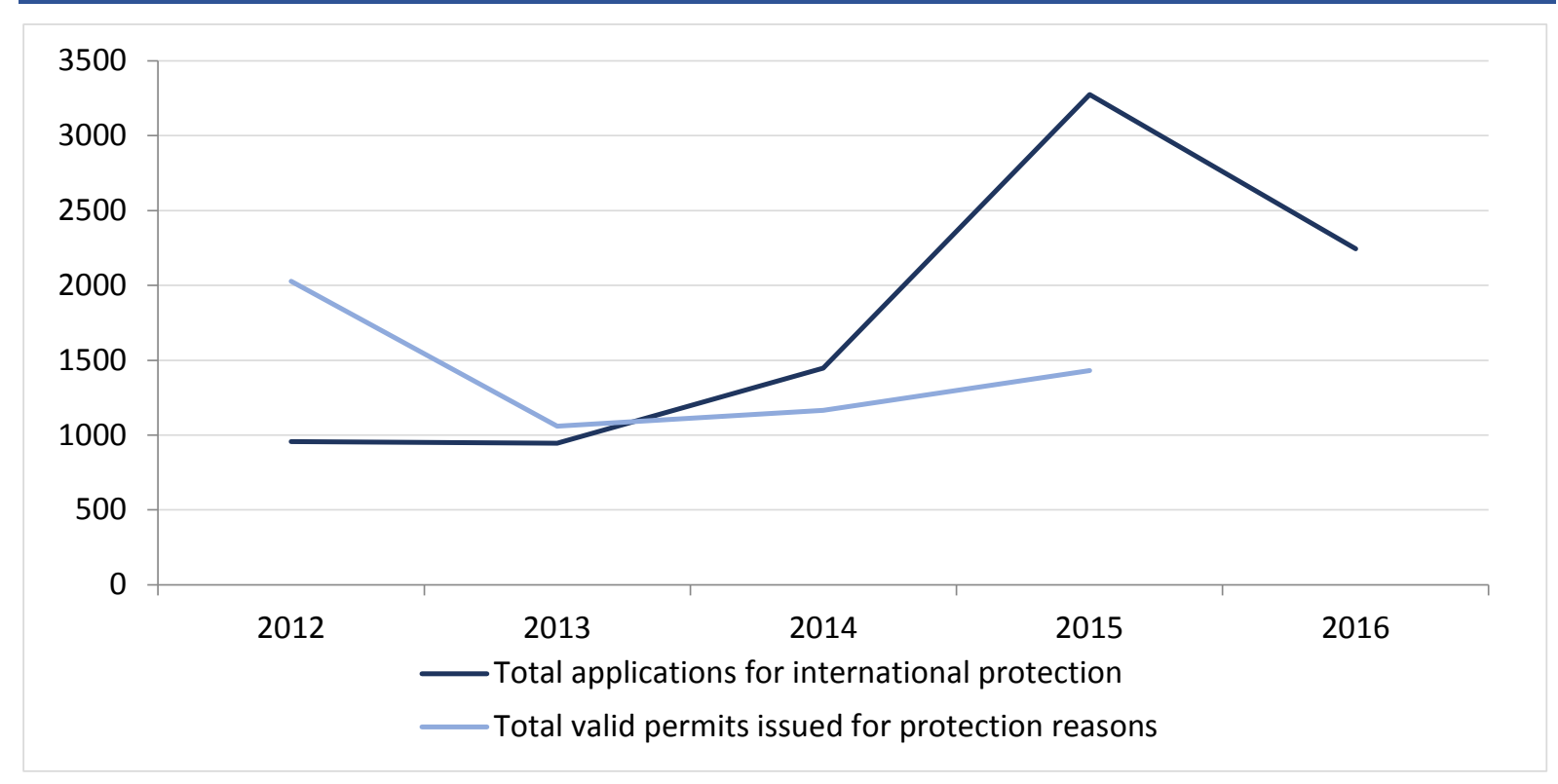

Source: ORAC, 2017; Eurostat [migr_resfas].

Note: $\quad$ Eurostat figures for all valid residence permits issued for protection reasons (i.e. on the basis of refugee status or subsidiary protection status) available to 2015 (no 2016 data available yet). 
Figure 3 shows that the number of valid permits ${ }^{23}$ issued for protection reasons decreased by 48 per cent from $2012(2,027)$ to $2013(1,059)$. The decrease could be related to the increase in naturalisation applications granted (Barrett et al., 2017). The number of valid permits has increased annually from 2013 to 2015 , increasing by 23 per cent from $2014(1,166)$ to $2015(1,430)$.

\subsubsection{Returns}

While no data are available on the rate of success in establishing the identity of 'rejected asylum seekers,' subject to a deportation order, Figure 4 shows that the total number of (forced) returns undertaken for all rejected applicants has increased in recent years. The number of forced returns increased by 272 per cent from 2014 (53) to 2015 (197) and 86 per cent from 2015 to 2016 (367). The top five nationalities of persons returned on foot of a deportation order in 2015 were: Nigerian, Chinese, DR Congolese, Algerian and Iraqi. Nigerians have been among the top five nationalities returned since 2012 (the start of the scope of this study).

FIGURE 4 TOTAL NUMBER OF FORCED RETURNS OF REJECTED APPLICANTS FOR INTERNATIONAL PROTECTION EFFECTED, 2012-2016

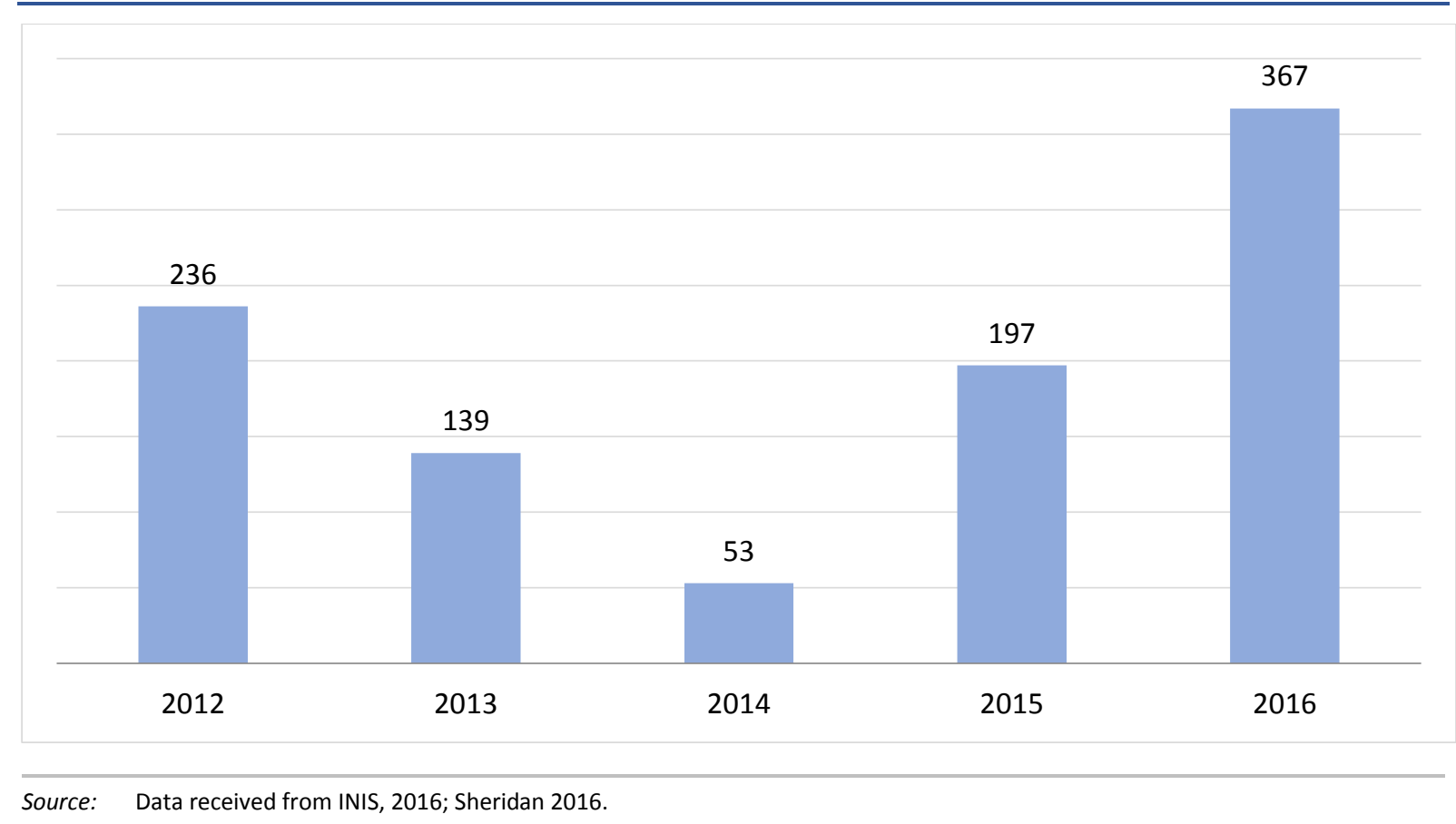

\subsection{METHODOLOGY}

This study collates data and information on national and EU policy, practice and legislation on establishing the identity of non-EEA nationals in the various

23 Valid residence permit means any authorisation valid for at least three months issued by the authorities of a Member State allowing a third-country national to stay legally on its territory. Eurostat [migr_resfas]. 
migration processes. Its purpose is to provide an evidence base for national and EU policymakers, researchers and practitioners working with non-EEA nationals including beneficiaries of international protection, as well as the general public. In Ireland, information on the identification requirements for non-EEA nationals is available online on the Irish Naturalisation and Immigration Service (INIS) website. However literature on establishing identity, and indeed on the challenges that may arise, remains sparse. The most recent piece of research on this topic in Ireland was the 2013 EMN study Establishing Identity for International Protection: Ireland (Joyce, 2013). However the scope of the 2013 study was limited to international protection applicants. This is the first comprehensive study to date on establishing identity in Ireland which outlines in detail the processes and practices concerning identity establishment with input from a variety of stakeholders. Furthermore this study takes account of the recent commencement of the International Protection Act 2015. Human trafficking and security related identity checks are outside the scope of this study.

The overall aim of this study is to provide an overview of the challenges faced by national authorities in their efforts to establish and verify the identity of non-EEA nationals within the context of asylum procedures, returns procedures and legal migration channels including applications for short-stay visas and applications for long-stay visas and residence permits for study, work, family and other reasons. Identity management issues related to the naturalisation process are outside the scope of this study. This study examines the approaches to establishing identity through the lens of two different and related tasks: identification and identity verification. Firstly, this study looks at identification procedures and systems (e.g. biometric systems) which seek to identify an unknown person, thus answering the question: 'Who is this person?' Secondly, this study examines the identity verification procedures and systems which aim to answer the question: 'Is this person who they say they are?' (European Migration Network, 2017). The temporal scope of analysis is January 2012 to December 2016. 2017 data are provided where available and relevant.

Desk research was undertaken at the outset of the study, including a review of existing academic and policy-based research as well as parliamentary and media debates. Interviews with stakeholders, in particular INIS, (see below) were key sources of information due to the paucity of literature and information available on establishing the identity of non-EEA nationals in migration processes in Ireland. National data on visa applications and deportation orders were obtained through INIS. National data on asylum applicants were obtained through the International Protection Office (IPO). National residence permit data were obtained through Eurostat. 
Interviews were undertaken with officials from INIS, the Garda Technical Bureau, the IPO and the Immigrant Council of Ireland. Outstanding information gaps were filled with comments from INIS and the GNIB. The report was internally and externally reviewed.

The information used to produce this report was gathered according to commonly agreed European Migration Network (EMN) specifications developed to facilitate comparability across countries. The $\mathrm{EMN}^{24}$ is tasked with producing studies on topics of relevance to policymakers at national and EU levels, in order to meet long- and short-term information needs. Topics may be proposed for indepth strategic studies with long-term relevance, or for shorter studies, responding to immediate information needs. Each EMN National Contact Point produces a national report, and a comparative, EU-level synthesis report is then produced, which brings together the main findings from the national reports and places them within an EU perspective. ${ }^{25}$ 



\section{SECTION 2}

\section{Establishing identity of non-EEA nationals in migration procedures}

\section{$2.1 \quad$ INTRODUCTION}

Any individual wishing to enter the State, whether visa required or not, is subject to immigration controls at ports of entry. All non-EEA (both visa required and non-visa required) nationals require permission to enter Ireland upon arrival. ${ }^{26}$ Visa required non-EEA nationals must apply for a visa to travel to Ireland. However, an Irish visa is a form of pre-entry clearance to travel to a point of entry to the State only (Quinn, 2011). This section outlines the processes and methods used in establishing and verifying the identity of non-EEA nationals during the visa application process, at ports of entry and upon registration for residence permission. The section also looks at establishing identity during the international protection determination procedure and in the context of forced return.

While establishing the identities of non-EEA nationals is particularly challenging in the protection (see Section 2.6) and returns procedures (see Section 2.7), challenges also exist within legal migration procedures (see Sections 2.4-2.6) (European Migration Network, 2017).

Section 2.2 outlines the various authorities responsible for establishing and verifying the identity of non-EEA nationals in Ireland. Section 2.3 introduces the documents used to establish the identities of non-EEA nationals in Ireland, including travel and other identification documents. Sections 2.4 to 2.7 outline the organisation of the identity establishment procedure in respect of non-EEA nationals in the following migration procedures: short- and long-stay visas, border control and registration for residence permits, international protection and forced returns. Sections 2.3 to 2.7 look at the measures used in each of the migration procedures, for example: fingerprinting, taking and sharing photographs, interviews, language analysis and DNA testing.

\subsection{ORGANISATION OF RESPONSIBLE AUTHORITIES}

Seven Member States and Norway have a central competence centre that is responsible for establishing identity and verifying documents. ${ }^{27}$ Competence centres are either departments within police authorities, ${ }^{28}$ immigration

\footnotetext{
26 Citizens Information, 'Permission to enter Ireland', citizensinformation.ie; Immigration Act 2004, as amended, section 4. 
services, ${ }^{29}$ ministries ${ }^{30}$ or asylum authorities, ${ }^{31}$ or independent authorities. ${ }^{32}$ For example the ID centre in Norway is an independent administrative body under the Norwegian Police Directorate, which provides support to national authorities (e.g. asylum, immigration and police) in establishing identity of non-EEA nationals. A number of Member States have also established databases for genuine and false documents and make use of other systems such as iFADO, PRADO and the EDISON system. These centres may also provide advisory services including training to other national authorities. Some of the centres also have a dedicated forensic document unit (Austria, Finland, Norway) (European Migration Network, 2017).

There is no central competence centre in Ireland for issues related to identification/identity verification of non-EEA nationals; as a result a number of bodies are involved. The Visa Division of the Irish Naturalisation and Immigration Service (INIS) is responsible for verifying the identity of visa applicants, in cooperation with other national authorities, such as the Garda National Immigration Bureau (GNIB) and the Garda Technical Bureau (GTB). ${ }^{33}$

The INIS Border Management Unit (BMU) in co-operation with other national authorities, such as the GNIB and the GTB, is responsible for front-line identity checks at Irish ports. ${ }^{34}$

The International Protection Office (IPO) has responsibility for making recommendations to the Minister as to whether applicants for international protection should be granted protection status. Credibility assessments are an essential part of the process and within that, establishing nationality/identity to a certain extent (see Section 2.6). ${ }^{35}$ Credibility assessment refers to

the process of gathering relevant information from the applicant, examining it in the light of all the information available to the decisionmaker, and determining whether the statements of the applicant relating to material elements of the claim can be accepted, for the purpose of the determination of qualification for refugee and/or subsidiary protection status (UNHCR 2013, 27). 
Officers of the INIS Registration Office and GNIB in Garda Districts outside Dublin are responsible for verifying the identity of non-EEA nationals upon registration once in the country. ${ }^{36}$ At this stage, however, non-EEA registrants have typically had their identity verified during a visa application process and/or at the border on arrival. ${ }^{37}$

The Repatriation Division of INIS is responsible for establishing the nationality of non-EEA nationals who are the subject of a deportation order where documents are missing or inadequate. This is done through contact with embassies. ${ }^{38}$ INIS has worked to build relationships with London-based third-country embassies in relation to addressing the challenges of travel documentation and identity verification (Sheridan, 2017).

The GTB Documents Section acts as a central competence centre for the verification of all documentation (Joyce, 2013). ${ }^{39}$ On receipt of a request from another body (e.g. IPO or the Visa Division), the GTB examines identity/travel/'breeder' documents (e.g. Passports, ID Cards, Birth Certificates, Marriage Certificates) to assess if an alteration, addition or obliteration has taken place and to determine if they are genuine or counterfeit. GTB also takes and stores fingerprints where required. ${ }^{40}$

\subsection{DOCUMENTATION REQUIREMENTS}

Consistent with practice across Europe (European Migration Network, 2017), in almost all cases an original passport or travel document is required in order for a third-country national to be issued a visa, to register in the State and to access the territory at the border. ${ }^{41}$ Protection applicants are not required to have a passport or travel document to access the asylum procedure (see Section 2.6). At the EU level, supporting documentation and copies of identity documents may be accepted by Member States in order to establish the identities of international protection applicants and in the returns procedure (European Migration Network, 2017).

INIS noted that the documentation supplied to prove a family relationship may differ from country of origin to country of origin. INIS noted that, above all, they

Non-EEA nationals residing outside Dublin must register with the nearest immigration registration office, managed by An Garda Síochána. Non-EEA nationals residing in Dublin must register with the INIS Registration Office in Dublin. INIS, 'Regional immigration registration offices', www.inis.gov.ie.

Interview with INIS (Registration Office), July 2017.

Interview/Consultation with INIS (Repatriation Division), August 2017.

The GTB Documents Section and Fingerprint Section hold ISO 17025 laboratory accreditation.

Interview with GTB Documents Section and Fingerprints Section, July 2017.

Some exceptions include: those travelling on verifiable UN or Interpol business or on a verifiable official (State) invitation and those travelling on a Seaman's Travel Document. 
encourage applicant family members and sponsors to supply passports or similar (Arnold and Quinn, 2017). However, other documents may be accepted as long as the family relationship is established and the sponsor's identity has been established (Arnold and Quinn, 2017). DNA testing may also be relied upon in family reunification cases where documentation is not viewed as sufficient (Joyce, 2013; Arnold and Quinn, 2017). ${ }^{42}$

Supporting documents may include: birth and divorce certificates, marriage licences, qualifications certificates, trade union cards, supporting letters (Joyce, 2013) and medical or other information confirming dependency or indeed family relationships in the case of family reunification (Arnold and Quinn, 2017).

A number of challenges to establishing identity have been documented in the context of family reunification applications, including providing sufficient documentary evidence to establish identities of and family links between the sponsor and the family member (Arnold and Quinn, 2017). The EU-wide synthesis report shows that a number of Member States face particular challenges to establishing the identity of family members in family reunification procedures, specifically in relation to establishing family links. These challenges were more significant in the context of international protection (European Migration Network, 2017).

The Irish Immigrant Support Centre (Nasc) has noted that quite often official documents from embassies or authorities in the country of origin contain mistakes, including spelling mistakes, or incorrect dates of birth (Arnold and Quinn, 2017). INIS observed that breeder documents in family reunification applications may be forged or altered or there may exist a number of authorities which can issue identification documents and register births, deaths and marriages (e.g. marriage documents may differ by region in Pakistan and Afghanistan). ${ }^{43}$

ICl (2016) reported that particular challenges may arise in the case of children. For example in one documented case, a child family reunification applicant was abandoned by her father, who was in possession of her passport. She was unable to produce identification as a result (Immigrant Council of Ireland, 2016).

In the context of family reunification applications where the sponsor is a beneficiary of international protection UNHCR has observed that the requirement 
to provide original documents from abroad can be challenging (Arnold and Quinn, 2017).

Supporting documents may be considered as contributing towards establishing an individual's credibility in the context of international protection (Joyce, 2013). Copies of supporting documents are accepted by the IPO, but the evidential value of copies is significantly lower than originals in establishing the credibility of material facts to a claim for protection. ${ }^{44}$ IPO reiterated that while some discretion may be shown in individual cases, a risk assessment is carried out to establish, for example, if the individual is from a country of origin with a history of immigration regulation abuse. In such cases, copies will not be accepted. ${ }^{45}$ In their analysis of Refugee Appeals Tribunal (now International Protection Appeals Tribunal) decisions, the Irish Refugee Council (2012) observed inconsistencies in what was accepted as an identity document (Joyce, 2013). Copies are not accepted for visa applications by INIS. ${ }^{46}$

Generally, ICl expressed concern about inconsistencies within and poor translations of applicants' documentation in Ireland. They also observed that establishing identity is often particularly challenging for stateless persons. ${ }^{47}$

\subsubsection{Document verification}

The EU-wide synthesis report shows that the majority of Member States have seen an increase in the number of forged/false identity documents since the 2013 EMN study on Establishing Identity for International Protection Challenges and Practices (European Migration Network, 2017).

Suspected documents are most commonly detected at ports of entry by BMU and GNIB officials and sent to the GTB (Documents Section) for formal examination. ${ }^{48}$

As noted above, the GTB examines identity, supporting and other documents upon request from other front-line agencies such as INIS and the IPO. ${ }^{49}$ The GTB (Documents Section) has access to the EU certified FRONTEX (European Border and Coast Guard Agency) training tool used by Member States in training immigration officers. The GTB also makes use of the EDISON system, a forensic 
database for second-line checks that contains examples of genuine travel documents, to help identify fakes, ${ }^{50}$ and DISCS (a Breeder document database) system (Joyce, 2013).

The GTB obtains specimen documents from Irish Embassies and through formal and informal contacts outside the EU. Documents related to the EU are automatically circulated to GTB. False documents are kept for comparison and training/outreach purposes by GTB, specifically the Document Section (Joyce, 2013).

In addition the GTB provides support and training to other national authorities on document verification, assists front-line officers where necessary, and provides advisory services to INIS (including Visa Division and BMU), IPO, Department of Social Protection, and the Department of Justice and Equality (Joyce, 2013).

The number of identity document (specifically passports, ID Card and Breeder documents) cases handled by the GTB (Document Section) in the first six months of 2017 shows an increase of 93 cases on the same period in 2016 (from 253 in 2016 to 346 in 2017).

There were a total of 536 cases referred to the GTB in 2016. Of the 385 completed cases, 277 (72 per cent) were passports and 74 (19 per cent) were identity cards. A further 34 ( 9 per cent) were breeder documents.

Some 104 passports and 52 identity cards were deemed invalid in 2016. This follows a decrease in the number of passports seized for examination each year from 2014 to 2016.

In 2016, identity documentation from Nigeria, Somalia, Pakistan and Ghana was most frequently seized for examination, while in 2015 it was Nigeria, Afghanistan, Pakistan and Somalia. In 2014, documents from Nigeria, Iraq, Zimbabwe and Afghanistan featured most frequently. ${ }^{51}$

The following sections look at the different migration processes and the different methods used. Documentation is revisited under each heading in addition to other methods used to establish or verify identity including fingerprinting, 
language analysis and interviews to determine probable country or region of origin (typically in the context of international protection) and DNA analysis (typically in the context of family reunification).

\subsection{VISA APPLICATIONS PROCESS: SHORT- AND LONG-STAY VISAS}

The Visa Division of INIS has responsibility for processing visa applications for the purposes of study, family and remunerated activities reasons. ${ }^{52}$

Applicants for short- and long-stay visas must apply online..$^{53}$ Once the application is made the applicant will be instructed to print the completed application form and sign it. ${ }^{54}$ The applicant must then present to the relevant embassy with the signed form along with supporting documentation including two colour passportsized photographs, not more than six months old and a current passport, valid for at least 12 months after proposed date of arrival and the specified documentation required in relation to the particular type of visa being requested (see below). The form contains the applicant's passport number, name, address and date of birth and acknowledges that INIS can share information with other Irish Government departments and with European and UK agencies including police forces. ${ }^{55}$ INIS visa officers (based in INIS in Dublin and seven visa offices abroad) assess the form and the supporting documentation including for the purposes of establishing/verifying identity. Trained INIS Visa officers abroad are assisted, in some instances, by local staff. ${ }^{56}$

The visa application process is largely uniform across visa types. In terms of documents, different requirements attach to visas issued for different reasons. For example applicants for family reunification with a beneficiary of international protection should provide birth certificates and national identity cards for each person named in the application (Arnold and Quinn, 2017).

Differences also exist for nationals from Nigeria, Pakistan, China and India and unaccompanied minor students. Visa applicants residing in Nigeria (irrespective of nationality), since 2010, are required to provide their biometric information (digital image of face and fingerprints) as part of the application process. Applicants from China, India, Nigeria and Pakistan are also required to provide fingerprints, which are then stored on An Garda Síochána Automated Fingerprint Identification System (AFIS). ${ }^{57}$ The AFIS, the national police fingerprints database,

\footnotetext{
Interview with INIS (Visa Division), June 2017.

INIS, 'Apply for an Irish Visa', www.inis.gov.ie.

Interview with INIS (Visa Division), June 2017.

Ibid.

Ibid.

Ibid.
} 
which is also used for the storage of asylum, registration and visa application fingerprints, is managed by An Garda Síochána. ${ }^{58}$

The capture of biometric information takes place when applicants residing in China, India, Nigeria and Pakistan present in person, unless exempt from the requirement to provide biometric information, at an Irish Visa Application Centre (VAC) operated by VFS Global. The requirement to provide visa biometrics at the application stage may be rolled out to other countries (Department of Justice and Equality, 2015). INIS (Visa Division) noted that biometric data provide an additional level of identity verification when available. ${ }^{59}$

Unaccompanied students under 18 must supply additional information including a birth certificate and parental consent from both parents/legal guardians and copies of the biometric page of the parents'/guardians' passports or national identity cards showing the bearer's signature. INIS (Visa) has used age analysis (blood/dental x-ray) in some applications from Bangladesh. ${ }^{60}$

Children under five years are not required to provide fingerprints but do require their own visa to enter Ireland.

\subsubsection{Verification process for visa applicants}

The photograph, signature, and date of birth submitted as part of the application are checked manually against the passport. INIS (Visa Division) seeks to find consistency across an individual's documentation and biography. ${ }^{61}$

INIS obtains specimens for comparison through the EU False Documents Working Group and through the Irish embassy network (Joyce, 2013). If the documents submitted by a visa applicant raise concerns they are sent to the GTB for examination. Fraudulent documents could result in a ban being imposed on the applicant. $^{62}$

The Visa Officer will also check visas from other countries in the passport submitted among other aspects of the applicant's immigration history in relation to Ireland, the UK, the Schengen zone, and other countries and check there is no

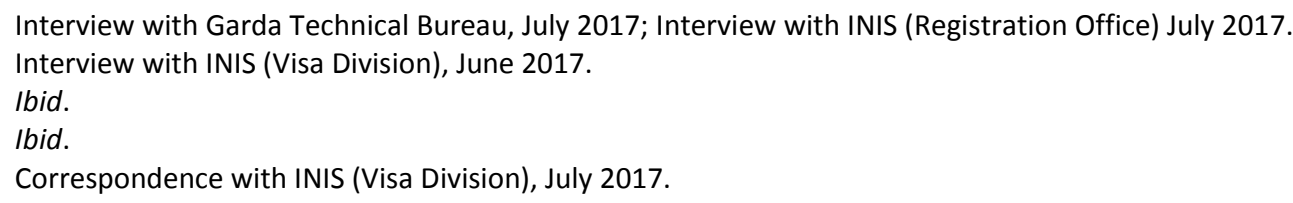


history of serious crimes or serious breaches of Irish or UK immigration law. Information related to previous visas issued is also checked. ${ }^{63}$

INIS may also use face-to-face and telephone interviews with applicants to verify identity. ${ }^{64}$

Previous visa applications (including photographs submitted) since 2009, including those refused, can be cross-checked through the Automated Visa Applications Tracking System (AVATS) which is managed by INIS. Biographical information and photographs for Visa applications are stored on the AVATS. AVATS can also store alerts if there has been a 'hit' in relation to negative immigration history or an Interpol 'hit'. This acts as an alert to prompt further background research. ${ }^{65}$ INIS intends to integrate internal INIS information databases into the AVATS system, so that the same information will be available to visa officers worldwide, including staff of the Department of Foreign Affairs in the embassies. ${ }^{66}$

\subsubsection{Co-operation with the UK on visa schemes}

Co-operation in relation to visa applications specifically and in relation to two visa schemes - the Irish Short Stay Visa Waiver Programme which was commenced in July 2011 and the British-Irish Visa Scheme (BIVS) which commenced in autumn 2014 - is central to Common Travel Area (CTA) co-operation. ${ }^{67}$

For the Irish Short Stay Visa Waiver Programme, the visa is a UK visa and the biometric and other checks are carried out by the UK authorities. A person who has been issued a UK short-stay visa from one of the countries covered by the Programme ${ }^{68}$ will be able to enter Ireland during the period of validity of the UK visa, once they have first landed in the UK during the period of validity of the visa, without the requirement to obtain a separate Irish visa. The scheme is not reciprocal - persons under this scheme will not be able to enter the UK on an

Interview with INIS (Visa Division), June 2017.

Ibid.

Ibid.

Ibid.

The legal basis for the Short Stay Visa Waiver Programme and for the BIVS is the Immigration Act 2004 (Visas) Order 2014 (S.I. 473 of 2014).

68 Belarus, Bosnia and Herzegovina, Montenegro, Russian Federation, Serbia, Turkey, Ukraine, Bahrain, Kuwait, Oman, Qatar, Saudi Arabia, United Arab Emirates, India, Kazakhstan, Peoples Republic of China, Thailand, Uzbekistan. See 'Short Stay Visa Waiver Programme' www.inis.gov.ie. 
Irish visa. ${ }^{69}$ In October 2016 the Short Stay Visa Waiver Programme was extended to $2021 .^{70}$

The BIVS allows for travel to and around the CTA on a single visa. Prior to autumn 2014, non-EEA tourists and business visitors who wished to visit both Ireland and the UK, including Northern Ireland, needed separate Irish and UK visas. ${ }^{71}$

Participation in the BIVS for applicants from China and India requires the submission of biometric information (photograph and ten fingerprints). Ireland and the UK operate joint Visa Application Centres in India and China. Visa applications for UK visas continue to be processed by the UK authorities and for Irish visas by the Irish authorities. ${ }^{72}$ The BIVS is a reciprocal visa scheme, and the biometric information - photographs and fingerprints - is checked through both the UK and Irish systems. ${ }^{73}$ The BIVS is considered by the Department of Justice and Equality as a landmark development in CTA co-operation. ${ }^{74}$

\subsubsection{Challenges}

The INIS Visa Division noted that establishing identity is an issue or challenge in the context of visa applications from third-country nationals where:

i. Ireland has no embassy;

ii. there may exist a number of authorities which can issue identification documents and register births, deaths and marriages (e.g. marriage documents may differ by region in Pakistan and Afghanistan);

iii. there may be a central register but not all citizens are registered or may not be registered years after their birth/marriage;

iv. official identification documents can be obtained in exchange for payment/bribes;

v. information provided to the official issuer is incorrect;

vi. identification documents can be procured in another individual's name and/or where passports are not machine-readable but hand written which are easier to forge;

vii. where the remoteness, terrain and/or political situation in some regions make administration and investigation difficult/dangerous; or

Interview with official, INIS Visa Division, June 2017.

Immigration Act 2004 (Visas) (Amendment) Order 2016 (S.I. No. 502 of 2016).

INIS, 'British-Irish Visa Scheme', www.inis.gov.ie.

UK Visas and Immigration, 'Guidance British-Irish Visa Scheme', www.gov.uk.

Interview with official, INIS Visa Division, June 2017.

INIS, Press Release: 'Minister Fitzgerald and UK Home Secretary launch landmark British-Irish Visa Scheme', www.inis.gov.ie.

$74 \quad$ Interview with official, INIS (Visa Division), June 2017. 
viii. when a country is moving from one form/style of identity documentation to another.

Other issues include, for example, the titular head of an extended family group being (incorrectly) identified as an applicant's biological father; extended family members (incorrectly but customarily) regarded as immediate/biological family, (multiple) name changes due to marriage or custom; individuals known only by forenames; applicants unable to write; and signatures presented in non-Roman script e.g. Urdu script. ${ }^{75}$

To overcome these challenges, INIS Visa Division co-operates with the GTB, and with UK and other EU visa processing centres, in responding to queries regarding visas granted or refused. It also co-operates with other Irish Government bodies for example the Department of Social Protection and the Revenue Commissioners. ${ }^{76}$

INIS noted that the collection of additional data elements (that are not collected at present), such as national identification/citizenship numbers from countries of origin would be useful where available for the purposes of assessing visa applications. $^{77}$

The EU-wide synthesis report shows that, a number of Member States encounter challenges in the processing of visa applications due to forged or counterfeit identity documents (European Migration Network, 2017). ${ }^{78}$

\subsection{ON ARRIVAL TO IRELAND: BORDER CONTROL AND THE REGISTRATION PROCESS}

\subsubsection{Border control}

As stated above, any individual wishing to enter the State, whether visa required or not, is subject to immigration controls at ports of entry. The Immigration Act 2004, section 11 provides that

Every person (other than a person under the age of 16 years) landing in the State shall be in possession of a valid passport or other equivalent document, issued by or on behalf of an authority recognised by the

Interview with INIS (Visa Division), June 2017.

Ibid.

Ibid.

Germany, Finland, France, Ireland, Poland, Portugal and Norway. 
Government, which establishes his or her identity and nationality to the satisfaction of an immigration officer.

Since 2015 the civilian BMU within INIS has responsibility for checking thirdcountry national identity and travel documents at Dublin Airport Terminal 1 and this civilianisation programme is expected to be fully rolled out to Terminal 2 during 2017 (Department of Justice and Equality, 2017a).

On arrival at the border, passport and visa documentation presented will be checked for validity by INIS immigration officers. This involves a manual examination of the travel documents by trained officers. These officers have access to the Interpol Lost and Stolen Passport database since 2016, ${ }^{79}$ the EDISON system (Department of Justice and Equality 2017a, 13), ${ }^{80}$ and to the GNIB-IS which records supporting documentation provided by the applicant (see Section 2.5.2). Sometimes biographical information may be entered into the GNIB-IS by a border control officer at the airport. This is for convenience of registration later. ${ }^{81}$

Advance Passenger Information (API) is not systematically analysed. If a person of interest presents, the INIS will use the provisions on carrier liability in the Immigration Act 2003, to ask the carrier for the flight manifest. ${ }^{82}$ From autumn 2017, the Irish immigration authorities will begin to automatically collect and analyse API data from carriers on inbound flights from outside the EU. ${ }^{83} \mathrm{An}$ API data processing unit will be established, including personnel from INIS and An Garda Síochána. The API data will be collected, run against relevant watch lists, analysed, and subsequent instructions sent to the relevant ports of entry. Ireland is also implementing the EU Directive (2016/681) on Passenger Name Records (PNR) (Department of Justice and Equality, 2017a) ${ }^{84}$ and, in time, both API and

This had previously been a back office check. Interview with INIS (Border Management Unit), 2017.

Interpol, 'Systems', www.interpol.int.

Interview with INIS (Border Management Unit), June 2017.

Carrier liability: Section 2(1) of the Immigration Act 2003 establishes carrier liability in relation to immigration compliance of passengers carried. Section 2(1) (c) provides that a carrier must ensure that that 'each non-national on board the vehicle seeking to land in the State or to pass through a port in the State in order to travel to another state has with him or her a valid passport or other equivalent document which establishes his or her identity and nationality and, if required by law, a valid Irish transit visa or a valid Irish visa.'

The Immigration Act 2003 (Carrier Liability) Regulations 2003 set out the form of the notice of an alleged offence under Section 2 of the Immigration Act 2003.

Transmission of Advanced Passenger Information (API) data: There is a legislative framework in place regulating provision of API data by carriers from outside the EU to the Irish authorities and, in certain circumstances, the provision of API data by Irish carriers to the authorities of other countries (United Kingdom).

Data collected in accordance with the Regulations 2011, transposing Directive 2004/82/EC 'API' Directive.

EU Directive 2016/681 on the use of passenger name record (PNR) data for the prevention, detection, investigation and prosecution of terrorist offences and serious crime. PNR data is defined in the EU Directive on Passenger Name Records as follows: 'a record of each passenger's travel requirements which contains information necessary to enable reservations to be processed and controlled by the booking and participating air carriers for each journey booked by 
PNR data will be screened in the same Passenger Information Unit (PIU). ${ }^{85}$ It is the intention of the Irish authorities to also collect intra-EU passenger data, as foreseen by the Directive. ${ }^{86}$ As of October 2017, the technical solution to process API was expected to be installed shortly and INIS indicated that API will then start to be collected on certain routes initially on a trial basis. Additionally, INIS indicated that, as required by the PNR Directive, a Director has been appointed to head up the Passenger Information Unit and has begun work to establish the Unit. ${ }^{87}$

The $\mathrm{GTB}^{88}$ also makes iFado, an online database containing false and authentic documents, available to border control officers and other immigration officers and government officials involved in the immigration process. ${ }^{89}$ BMU staff can contact the GTB (Documents Section) if serious concerns are raised in relation to documentation.

Individuals can also be interviewed to assess credibility and can be refused entry to the State and returned if concerns are raised at this point. Immigration Officers may also require fingerprints on arrival at an Irish port of entry.

\subsubsection{Registration}

Non-EEA nationals who are resident for longer than 90 days in Ireland are required to register with the GNIB or, in Dublin, at the Registration Office operated by INIS. Particulars to be furnished on registration are set out in section 9 of the Immigration Act 2004 (see Table 1). At the time of registration, biographical and biometric information is saved in the GNIB-IS. Where machinereadable passports are available, the machine-readable zone is scanned and the GNIB-IS is automatically populated..$^{90}$ INIS seeks to establish consistency between visa and residency applications and the individual presenting at the Registration Office. ${ }^{91}$ Concerns raised by Immigration Officers working on registrations will be brought to the attention of GNIB and/or INIS (Visa Investigation Section).

or on behalf of any person, whether it is contained in reservation systems, departure control systems used to check passengers onto flights, or equivalent systems providing the same functionalities.'

Interview with official, Border Management Unit, INIS, June 2017.

Ibid.

Correspondence with INIS, Border Management Unit, Irish Naturalisation and Immigration Service, October 2017.

The GTB is the national administrator for the iFADO portal for false and authentic documents at border.

Interview with Garda Technical Bureau, July 2017.

Consultation with GNIB, August 2017.

Interview with INIS (Registration Office), July 2017 
TABLE 1

INFORMATION AND DOCUMENTATION TO BE FURNISHED BY NON-EEA NATIONALS AT TIME OF REGISTRATION WITH GNIB/INIS

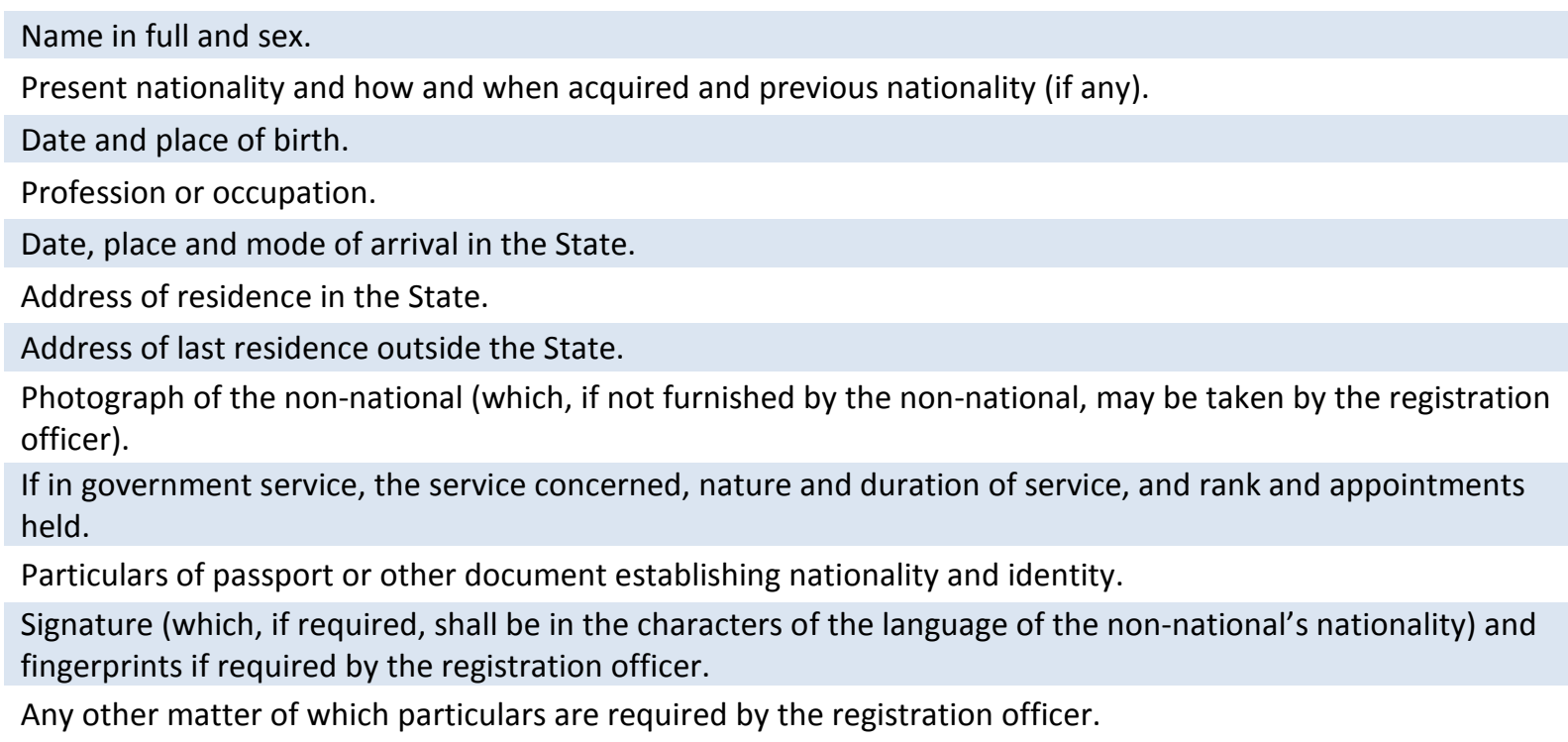

Source: Immigration Act 2004, section 9.

A photograph is taken at registration for use on the registration card (known as a GNIB card) and to be stored on GNIB-IS. The Uniform Format Residence Permit, in accordance with Council Regulation (EC) 1030/2002, will be rolled out from autumn 2017. ${ }^{92}$ The Regulation sets out the general characteristics of the uniform format for residence permits issued by EU Member States. INIS (Registration Office) will have access to $\mathrm{ICAO}^{93}$ compliant cameras in the future (a pilot is planned for the last quarter of 2017). There are currently no plans to compare the photographs with national and European databases. ${ }^{94}$

Ten fingerprints are taken at first registration. ${ }^{95}$ These ten fingerprints are saved on the Garda AFIS system. ${ }^{96}$ Fingerprints from two index fingers are taken to be used for verification purposes at renewal of registration. These two index fingerprints are saved on the GNIB-IS. ${ }^{97}$

In response to a Parliamentary Question (PQ) on the use of fingerprinting by GNIB, the Minister for Justice described fingerprinting as being recognised internationally, with other biometric identifiers, as an essential and reliable method of identity verification and a key technology to combat identity fraud and to enhance the security and integrity of documentation such as the registration 
certificate issued to a non-national. ${ }^{98}$ The GTB considers fingerprints to be the best biometric identifier. ${ }^{99}$

The IPO considers fingerprints probative when matching people to previous fingerprints, ${ }^{100}$ but fingerprints do not establish identity. ${ }^{101}$ In some cases fingerprint matches are associated with different identities, i.e. names, dates of birth, nationalities, etc. ${ }^{102}$

\subsubsection{Challenges}

In relation to travel documents presented at the border, the BMU and GTB (Documents Section) identify as the major issues: a) poor quality/damaged genuine documents carried by genuine owner; b) genuine documents carried by an impostor; and c) new travel documents issued by non-EU authorities, the features of which are not yet familiar to front-line staff. The use of forged or falsified EU ID cards is also a major issue.

The INIS Registration Office notes that establishing identity is a challenge in the context of residence permits for family, study and remunerated activities, where the applicant has a non-machine readable/non-electronic passport and therefore cannot be checked instantaneously against Interpol's Lost and Stolen Passport database via GNIB.

INIS noted that a single search facility for officers at border control which could check against all databases would be useful but is not immediately planned. ${ }^{103}$

In the context of visas, as documentation is submitted prior to arrival in the country, this presents fewer challenges in the context of establishing identity than in cases of international protection where there may be no prior documentation available for comparative purposes (see Section 2.6).

With reference to the registration of a Syrian child, $\mathrm{ICI}$ reported difficulties in obtaining a valid passport from the country of origin due to war or political instability (Immigrant Council of Ireland, 2016).

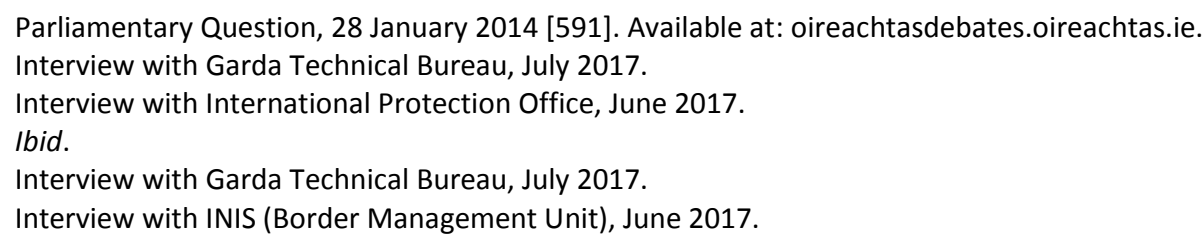




\subsection{INTERNATIONAL PROTECTION}

On presenting at the IPO (previously ORAC) offices, an initial interview is carried out in accordance with section 13 of the International Protection Act 2015. This is known as a section 13 interview and typically takes place in the IPO office. In Ireland (ORAC, 2015) and across Europe (European Migration Network, 2017) the primary objective is to establish the applicant's country of origin and/or credibility of protection claim rather than to establish identity. Biographical data are collected including name, date of birth, address in country of origin, address in Ireland, sex, marital status, and children or other family members. Language assessment may be used to assist in determining nationality, but this is uncommon (ORAC, 2015).

All applicants are photographed and provided with a temporary registration card as evidence that they have applied for protection (Joyce, 2013, 6).

If the applicant for protection presents at the border, basic details (e.g. name, address) are taken by the immigration officers and, on occasion, fingerprints are taken. Fingerprinting usually takes place at the IPO.

New fingerprinting software has been installed in the IPO for the application of the Eurodac Fingerprinting Regulation (Regulation (EU) 603/2013) which came into operation in July 2015 (ORAC, 2015, 18). Fingerprints are taken for all protection applicants (over 14 years) for the purposes of Eurodac. Fingerprints for the purpose of checks on the Eurodac system are stored on the AFIS (see Section 1) (ORAC, 2015, 18).

The IPO may also check data with that of the UK visa system in accordance with Article 34 of the Dublin Regulation. ${ }^{104}$ Article 34 provides for the sharing of information, such as personal details of the applicants, identity documents, residence documents or visas issued, between Member States 'as appropriate, relevant and non-excessive' (34.1) (see Section 3.4).

The IPO also has access to the AVATS and the e-Visa system of INIS (ORAC, 2015, 28). The IPO also maintains its own Caseworker's Shared Knowledge Database (ORAC, 2015, 20; ORAC, 2013, 18). 
After the section 13 interview the applicant completes a questionnaire which includes a list of documentation they are advised to provide: passport; national identity card; drivers licence; travel documents; birth, death and marriage certificates, as appropriate.

Pursuant to section 2 of the International Protection Act 2015, 'identity document' includes: a passport, visa, transit visa, national identity card, entry permit, residence permit, driving licence, employment permit, birth certificate, marriage certificate or any other document establishing or contributing to establishing a person's nationality or identity issued or purporting to be issued by or on behalf of a local or the national authority of a state, including the State, or by an organ or agency of the United Nations.

Documents may be sent to the GTB (Document Section) for verification if there exists doubt as to the authenticity of the documentation to the extent that the credibility of the applicant might be impacted. The synthesis report shows that several Member States have found that determining the authenticity of documents provided by applicants was also a challenge (European Migration Network, 2017).

In the absence of valid travel documents, the IPO seeks to establish consistency within an individual's claim to a certain country of origin.

On receipt of the completed questionnaire, the substantive interview is scheduled with an IPO caseworker. IPO do not confiscate mobile or other devices nor access their content. If such content is offered during an interview, it will be viewed and noted. ${ }^{105}$

The following applicant details are recorded: name, other names, gender, marital status, date of birth/approximate date of birth, date of death (associated claims), current address, previous addresses, Eircode (Irish postal code system), email addresses, contact numbers, mobile phone numbers, and photograph. These are stored on the INIS case management database - AISIP. AISIP, an internal case management system, is managed by the INIS. AISIP generates a Person Identity Number for each protection applicant. ${ }^{106}$ Biographical data are pulled from AISIP to the IPO case management system in relation to each application. The IPO case 
management system is essentially a tracking system and most information in relation to a case is kept on a paper file. ${ }^{107}$

Establishing identity is not an objective of the international protection process in Ireland. It is therefore possible that an applicant who has not been able to provide evidence as to their identity where no evidence to the contrary has been presented/found may still receive a positive decision (Joyce, 2013). However, country reports from five Member States - Cyprus, Malta, the Netherlands, Poland and Slovakia - plus Norway noted that the failure to establish identity will lead to a negative asylum decision (European Migration Network, 2017). ${ }^{108}$

Establishing material facts, such as nationality/origin/ethnicity/membership of social groups etc. is one objective of the asylum determination process. Applicants who provide credible identity documentation greatly facilitate the examination of a person's claim, and greatly assist in establishing the credibility of the applicant. The benefit of the doubt is provided to applicants regarding their identity and/or nationality in the absence of conflicting, and presence of supporting, information (Joyce, 2013).

\subsubsection{Challenges}

Establishing identity is considered an issue within the framework for all migration procedures, but particularly challenging in the context of international protection and forced returns of persons who have exhausted the asylum system and are subject to a deportation order (Joyce, 2013).

The IPO identified a lack of any identity documents as a significant challenge. The majority of applicants for international protection do not have any documentation on file. ${ }^{109}$

The IPO also identified falsified documentation as an issue, noting that documents may be found to be forged, tampered with, or genuine but belonging to another person. Assessing the evidential value of documents is particularly challenging where non-biometric documentation such as birth certificates etc. are provided. Challenges also arise where individuals are from countries without a recognised functioning authority; where it is suspected or known that false 
documentation may be easily procured; or when poor quality, or poor condition but genuine, travel documents are presented. ${ }^{110}$

The IPO and the BMU also identify as a major issue the presence of authentic documents fraudulently obtained. The most common manifestations are persons presenting with forged or falsified EU ID Cards and persons who have obtained genuine passports by fraudulent means and are therefore not entitled to hold such passports. ${ }^{111}$

The IPO noted that establishing the credibility of those who claim protection remains a significant challenge. ${ }^{112}$ There is a wealth of literature criticising credibility assessments in the asylum process in Ireland including an Irish Refugee Council (2012) study and, more recently, an Irish Law Times article (Kane 2016) which identifies credibility assessments as a frequent subject of appeals and judicial reviews.

\subsection{FORCED RETURNS}

The Repatriation Division of INIS is responsible for establishing the nationality of non-EEA nationals who are the subject of a deportation order. This is done through contact with embassies. The Repatriation Division will contact the (presumed) embassy of the person subject to a deportation order. Rejected asylum applicants are interviewed by the embassies of the presumed country of nationality in the presence of Irish authorities. The Irish authorities provide the embassies with supporting documents on file and submitted by the applicant, including national passports. Photographs of persons subject to forced returns are not automatically taken unless the case concerns a criminal issue. However a photograph of the individual will be supplied to the embassy in the case of a phone interview (Joyce, 2013). This process serves to establish nationality more so than identity (Joyce, 2013). ${ }^{113}$

DNA analysis of applicants refused asylum and subject to a deportation order rarely takes place. DNA testing may be required where the subject of a deportation order makes an appeal and applies for residency on the basis of being a parent of Irish citizen children in light of the Zambrano judgment. ${ }^{114} \mathrm{~A}$ return decision can only be deferred in this case following the production of verifiable DNA evidence (Joyce, 2013).

\footnotetext{
Interview with International Protection Office, June 2017.

Interview with International Protection Office, June 2017; Interview with INIS (BMU), June 2017.

Interview with International Protection Office, June 2017.

Consultation with INIS Repatriation, August 2017.

CJEU, Case C-34/09 - Gerardo Ruiz Zambrano v. Office National de l'Emploi.
} 


\subsubsection{Challenges}

A proportion of rejected asylum seekers cannot be returned to their country of origin due to the fact that measures used to establish identity are not always successful (Joyce, 2013; Sheridan, 2017). Difficulties arise where an embassy is not satisfied that the individual is a national of that country.

The INIS indicated that obtaining returnees' identification and/or travel documents from certain non-EU countries can be difficult and that this represents a significant challenge to the enforcement of deportation orders (Quinn and Gusciute, 2015). The returns process has been identified by the Department of Justice and Equality as resource intensive (Joyce, 2013).

INIS officials noted that obstacles are still likely to be encountered in relation to the identification or recognition of the nationality of returnees and the sourcing of the necessary travel documents. While INIS has actively cultivated links and informal readmission arrangements with those third countries to which Ireland regularly returns persons, and such arrangements have proven useful, officials note that they have limitations and have no binding legal effect. Ireland, unlike many other EU Member States, does not have a framework of bilateral agreements with third countries for the readmission of their own nationals found to be in an irregular situation in the Irish State (Quinn and Gusciute, 2015).

The EU-level synthesis report shows that Member States identified two key challenges in the context of establishing the identity of persons subject to a forced returns decision. Firstly, some Member States observed that persons with returns decisions failed to provide or withheld identity documents or made false statements as to their nationality or identity. Secondly some country reports highlighted difficulties establishing co-operation with third countries' authorities for the purpose of return (European Migration Network, 2017). 


\section{SECTION 3}

\section{Data protection safeguards}

\subsection{INTRODUCTION}

There is a balance to be struck between the legitimate interest of controlling migration regarding establishing the identity of non-EEA nationals via data sharing or holding data in large databases, and the privacy rights of the individual also enshrined in EU law (Article 29 Data Protection Working Party, 2013). This is achieved in Ireland by the provisions of the Data Protection Acts 1988 and 2003, which apply to all processing of personal data in the migration context.

Section 3.2 outlines the legislative framework to enable data sharing with appropriate data protection safeguards in relation to co-operation with the United Kingdom on securing the Common Travel Area (CTA) and for the sharing of advance passenger information (API). Sections 3.3 and 3.4 outline the national data protection supervision arrangements for Eurodac, including inspections and audits. Section 3.5 discusses complaints and summarises a legal challenge which relates to Article 34 requests under the Eurodac.

\subsection{DATA SHARING - LEGAL FRAMEWORK}

\subsubsection{Common Travel Area of Ireland and the United Kingdom}

Ireland and the United Kingdom have co-operated closely on securing the external borders of the CTA of Ireland and the United Kingdom since $1922 .{ }^{115} \mathrm{~A}$ central feature of the operation of the CTA has been that each state enforces the other's conditions of landing for non-EEA nationals. Thus a non-EEA national can be refused entry to Ireland on the basis that they would not meet the immigration conditions to enter the UK pursuant to section $4(3)(h)$ of the Immigration Act 2004.

In December 2011 the Minister for Justice and the UK Minister for Immigration agreed a Joint Statement on CTA co-operation which included a joint work programme in the area of data sharing, visas and electronic border management

115 The Common Travel Area is not a formal Treaty between Ireland and the UK. This has been clarified in parliamentary debate: 'Notwithstanding that it is referenced in the Treaty on the Functioning of the European Union, the Common Travel Area is an agreement between Ireland and the UK that has manifested in law, rather than itself being a matter of any legal treaty between the two states.' Speech by Minister of State, Damien English TD on behalf of the Minister for Justice and Equality, Frances Fitzgerald TD, Private Members' Freedom of Movement (Common Travel Area) (Travel Documentation) Bill 2014 - Deputy Terence Flanagan - Dáil Éireann, Second Stage, 13 November 2015. 
systems. ${ }^{116}$ Visa data are shared for the purpose of the implementation of the Irish Short Stay Visa Waiver Programme and the BIVS. Types of information shared between Ireland and the UK include:

- Visa data - biographical details are shared in relation to all visa applicants and biometric details are shared in relation to applications from Nigeria, India, Pakistan and China (as discussed in Section 2.4);

- Immigration history warnings;

- Information relating to expulsion orders; ${ }^{117}$

- Information relating to deportation orders. ${ }^{118}$

As well as the Joint Statement on CTA co-operation there are a number of Annexes which cover arrangements for the transfer of personal data in relation to co-operation on visa applications. The first Annex covers the automatic transfer of data in relation to the BIVS or checks with the UK immigration system for any negative immigration history. The second Annex covers day-to-day information sharing between officials of both Ireland and the United Kingdom in relation to visa applications. ${ }^{119}$

\subsubsection{Advance Passenger Information}

The European Communities (Communication of Passenger Data) Regulations 2011 transposed Council Directive 2004/82/EC on the obligation of carriers to communicate passenger data into Irish law. The Regulations apply to all inbound flights to Ireland from outside the EU and the data shared are API data i.e. the data on the machine-readable zone of the passport.

At present, API data are not systematically analysed. If a person of interest presents, the INIS will use the provisions on carrier liability in the Immigration Act 2003 to ask the carrier for the flight manifest. ${ }^{120}$ From autumn 2017, the Irish

The Joint Statement identified a number of aims for CTA co-operation including: To facilitate the movement of legitimate travellers within the CTA; To identify and develop further measures to enhance economic development between the two jurisdictions; To prevent individuals intent on abusing the arrangement from travelling to the CTA; To support and facilitate the return of individuals to their country of origin where they do reach or enter the CTA unlawfully; and To develop ways of challenging the credibility of visa and asylum applications where appropriate and develop mechanisms of re-documentation. Speech by Minister of State, Damien English TD on behalf of the Minister for Justice and Equality, Frances Fitzgerald TD, Private Members' Freedom of Movement (Common Travel Area) (Travel Documentation) Bill 2014 - Deputy Terence Flanagan - Dáil Éireann, Second Stage, 13 November 2015.

117 The removal of a non-EEA subject to an expulsion decision based on a serious and present threat to public order or to national security. For more information, see European Migration Network, 2014.

Interview with INIS (Border Management Unit), June 2017.

Interview with official, INIS Visa Division, June 2017.

Carrier liability: Section 2(1) of the Immigration Act 2003 establishes carrier liability in relation to immigration compliance of passengers carried. Section 2(1) (c) provides that a carrier must ensure that that 'each non-national on board the vehicle seeking to land in the State or to pass through a port in the State in order to travel to another state has with him or her a valid passport or other equivalent document which establishes his or her identity and nationality and, if required by law, a valid Irish transit visa or a valid Irish visa.' The Immigration Act 2003 (Carrier 
immigration authorities will begin to automatically collect and analyse API Data from carriers on inbound flights from outside the EU (see Section 2.5.1). INIS noted that API data must be deleted within 24 hours, unless related to a person of interest. ${ }^{121}$

Two sets of Regulations - the Data Protection Act 1988 (Section 2A) Regulations 2013 (S.I. No. 313 of 2013) and the Data Protection Act 1988 (Section 2A) Regulations 2016 (S.I. No. 220 of 2016) are in place to provide a legal base for Irish carriers to provide API data to the UK authorities.

The Data Protection Acts 1988 and 2003 set out the conditions which must be met by data controllers to process personal data. One of these conditions is when the processing of the data is necessary for the pursuit of legitimate interests of the data controller or by third part(ies) to whom the data are disclosed (except where the processing is unwarranted in any particular case by reasons of prejudice to the fundamental rights and freedoms or legitimate interests of the data subject). ${ }^{122}$ The Acts further provide that the Minister for Justice and Equality may, after consultation with the Data Protection Commissioner (DPC), make Regulations, specifying particular circumstances where this particular condition is met.

The Data Protection Act 1988 (Section 2A) Regulations 2013 (S.I. No. 313 of 2013) and the Data Protection Act 1988 (Section 2A) Regulations 2016 (S.I. No. 220 of 2016) are in place to provide a legal base to satisfy the legitimate interest condition in the Data Protection Acts, as described in the previous paragraph. The Data Protection Act 1988 (Section 2A) Regulations 2013 relate to the disclosure by an Irish air carrier of passenger data (API data) to the United Kingdom for flights which originate outside the CTA between Ireland and the United Kingdom. The Data Protection Act 1988 (Section 2A) Regulations 2016 relate to the transfer of API data by Irish air and sea carriers to the United Kingdom in relation to journeys which occur between Ireland and the United Kingdom, i.e. within the CTA.

These Regulations are enabling provisions to allow carriers to meet the conditions set out in data protection legislation to transfer API data to the United Kingdom. They do not compel carriers to do so and the actual transfer of the API data is a matter between the carriers and the UK Home Office. The Border Management

Liability) Regulations 2003 set out the form of the notice of an alleged offence under section 2 of the Immigration Act 2003. 
Unit noted that the Irish authorities, however, encourage Irish carriers to be cooperative. $^{123}$

\subsection{NATIONAL DATA PROTECTION SUPERVISION - EURODAC}

As mentioned in Section 1, Ireland exercised its right to participate in the Eurodac Regulation. The Data Protection Commissioner (DPC) is the national supervisory authority established pursuant to Council Regulation 2725/2000 and later, the Eurodac Regulation for Ireland. This function of the DPC is provided for in section 9(1A) of the Data Protection Act 1988, as inserted by the Data Protection Act 2003. A mirroring provision has been included in Head 8 of the General Scheme of the Data Protection Bill 2017. ${ }^{124}$

At EU level, pursuant to Article 31, the European Data Protection Supervisor (EDPS) has supervisory competence for the central Eurodac system. Article 32 of Regulation 603/2013 also provides for co-operation between the EDPS and the national supervisory authorities, regarding their respective responsibilities in the supervision of Eurodac. To this end, the EDPS and the national supervisory authorities meet and co-ordinate activities in the framework of a Supervision Coordination Group. ${ }^{125}$ The Supervision Coordination Group produces a Joint Activity Report every two years. The Irish supervisory authority, the Data Protection Commissioner (DPC), is represented on the Supervision Coordination Group.

\subsection{DATA PROTECTION INSPECTIONS AND AUDITS}

The DPC has powers under the Data Protection Act 1988, as amended (Sections $10(1 \mathrm{~A})$ and $(1 \mathrm{~B})$ in relation to conducting audits to ensure compliance with data protection legislation. These audits usually take the form of audits of selected organisations. The aim of an audit is to identify any issues of concern about the way the organisation deals with personal data and to recommend solutions. ${ }^{126}$ Reports of audits are not published by the DPC, although audited organisations may choose to make the report available in their own right.

An inspection of the Office of the Refugee Applications Commissioner (ORAC)/Eurodac was conducted by the DPC in 2016. The inspection report is not published (Data Protection Commissioner of Ireland, 2017).

\footnotetext{
Interview with INIS (Border Management Unit), June 2017.

General Scheme of Data Protection Bill (May 2017), www.justice.ie.

See: Eurodac, 'Supervision Coordination Group', www.edps.europa.eu.

Data Protection Commissioner, 'Audits', www.dataprotection.ie.
} 
In 2017, the DPC conducted a desk audit of Eurodac concerning data subjects' rights of access and rectification. ${ }^{127}$ The IPO outlined to the DPC that applicants applying for international protection at the IPO are given three documents containing information on how data about them will be collected and used. The three documents are the Information Booklet for IPO; information on the Dublin system; and information on the collection of fingerprints for Eurodac. ${ }^{128}$ In addition a notice on accessing personal information in accordance with section 4 of the Data Protection Acts 1988 and 2003 is included on the IPO website. ${ }^{129}$

The audit findings of the DPC concluded that there is clear and transparent information provided to applicants for international protection at the IPO on their rights to access and/or rectifies their personal data as required under the Dublin Regulation (EU) 604/2013 and in compliance with the Data Protection Acts 1988 and 2003. ${ }^{130}$

\subsection{COMPLAINTS AND LEGAL CHALLENGES}

According to the Joint Activity Report 2014-2015, the Irish Data Protection Authority (DPA) received three complaints in December 2015 regarding the submission of 'Article 34 checks' to the UK.

Article 34 allows Member States to request applicant data from other Member States for determining the Member State responsible for assessing the asylum claim, examining the application for international protection and for implementing any other obligation under the Dublin III Regulation. The Activity Report indicated that an investigation was to be commenced in 2016 and was to include an inspection (Eurodac Supervision Coordination Group, 2016).

There was an interesting piece of jurisprudence in Ireland concerning Eurodac and data protection in 2017. BS and RS v. the Refugee Appeals Tribunal dealt with the right to an individually enforceable effective remedy in the context of Article 34 of the Dublin III Regulation, which deals with information requests between national authorities. The appellants argued that an unlawful request from the Office of the Refugee Applications Commissioner to the United Kingdom was made, breaching the principle of preventing unauthorised disclosure under the Data Protection Directives 95/46/EC and the right to the protection of privacy (Article 8 of the EU Charter of Fundamental Rights). The appellants argued that this unlawful request resulted in unauthorised disclosure of personal information

\footnotetext{
See: Data Protection Commissioner, 'Audits', www.dataprotection.ie. Correspondence with Data Protection Commissioner, June 2017. See: International Protection Office, 'Data Protection', www.ipo.gov.ie. Correspondence with Data Protection Commissioner, June 2017.
} 
regarding the applicants in the reply to the request. The court did not find in the appellants' favour, finding that the test of legitimate interest for providing the personal data in the request to the United Kingdom had been fully met (see Annex A for full summary). 


\section{SECTION 4}

\section{Conclusions}

Establishing identity is often the first step in determining eligibility for visas and certain residency or visitor permissions. It is considered to be a challenge across the EU (European Migration Network, 2017). In the public domain, key debates in relation to establishing the identity of non-EEA nationals include concerns raised by NGOs relating to consistency in decision-making, including in the context of credibility assessments of asylum applicants, difficulties applicants and authorities face in obtaining documents, and data protection, specifically in relation to information sharing with other countries. Security and terrorism, in light of events in Europe, have also been subjects of debate in Dáil Éireann (parliament) and media.

This study looked at the processes in place for establishing the identities of applicants for short- and long-stay visas, residence and visitor permissions, international protection and permission to remain, and persons subject to a deportation order who have exhausted the asylum process. All non-EEA (both visa required and non-visa required) nationals require permission to enter Ireland upon arrival in accordance with section 4 of the Immigration Act 2004, as amended. Visa required non-EEA nationals must apply for a visa to travel to Ireland. However, an Irish visa is a form of pre-entry clearance to travel to a point of entry to the state only (Quinn, 2011). This study therefore also looked at identity establishment on arrival at points of entry to the territory.

Within the EU establishing the identity of persons in legal migration channels such as short- and long-stay visas and residence permits is partially governed by law and policy at EU level in the areas of visas (the Visa Code), family reunification (Family Reunification Directive), international protection (Recast Qualification Directive, Dublin III Regulation, and Eurodac Regulation) and return (Return Directive).

While Ireland did not exercise its right to opt-in to the Family Reunification Directive, the Recast Qualification Directive, Recast Procedures Directive or the Return Directive, Ireland does participate in the Dublin Regulation and Eurodac Regulation. This means that the establishment of the identities of non-EEA nationals in the context of migration procedures in Ireland is largely governed by national law and policy. Identity in the context of legal migration (short- and longstay visas and residence permissions) is governed by the Immigration Act 2004, as 
amended. Identity in the context of international protection is governed by the International Protection Act 2015 (see Section 2.6).

Ireland lies outside the Schengen area and as such the Visa Code and other border related aspects of the Schengen acquis do not apply. However Ireland is part of the Common Travel Area (CTA) with United Kingdom. The implications of this are that Ireland and the United Kingdom co-operate to secure external borders of the CTA and share visa data for this purpose (discussed below).

\subsection{DOCUMENTATION AND BIOMETRIC INFORMATION}

In almost all cases a passport or travel document is required for a non-EEA national to be issued a visa, to register in the State and to access the territory at the border. Protection applicants are not required to have a passport or travel document to access the asylum procedure. Beneficiaries of international protection may never have submitted identification documents, if their general credibility has been accepted. Family members of beneficiaries of international protection are encouraged to submit a passport or travel document, but where this is not possible, the family member may still be able to establish their identity utilising other forms of identification.

Fingerprints are considered probative when matching people to previous fingerprints, but fingerprints do not establish identity, and in many cases where there is a fingerprint match, different identities - names, dates of birth, nationalities, etc. - have been provided by the person concerned. In addition, language analysis and interviews to determine probable country or region of origin (typically in the context of international protection), and DNA analysis (typically in the context of family reunification) may be used.

\subsection{LEGISLATION AND POLICY REFORM}

A number of legislative and policy reforms in respect of establishing the identities of non-EEA nationals have been introduced since publication of the $2013 \mathrm{EMN}$ study Establishing Identity for International Protection: Ireland (Joyce, 2013).

The International Protection Act 2015, which came into effect in 2017 (commenced 31 December, 2016), provides for the return of rejected protection applicants. In addition civilian staff from the BMU within INIS have begun to replace members of the GNIB in carrying out front-line identity checks at Irish ports. 
The British-Irish Visa Scheme (BIVS) was commenced in autumn 2014, it allows for travel to and around the Common Travel Area on a single visa.

\subsection{DATA SHARING AND PROTECTION}

Identity establishment requires reliance on national and international databases and co-operation with other Member States as well as third countries. The main information systems which support identity management in migration processes developed by the EU are the SIS II, VIS and Eurodac. Ireland does not have access to VIS and at present does not have access to SIS II. Ireland's national project for connection to SIS II in relation to certain non-border related aspects is currently being developed.

Ireland and the United Kingdom co-operate closely on jointly securing the external borders of the CTA. Visa data are shared for the purpose of the implementation of the Irish Short Stay Visa Waiver Programme and the BritishIrish Visa Scheme. The implications of Brexit on these arrangements are unknown.

At present API data are not systematically analysed. Ireland introduced new regulations last year, which provide a legal basis under data protection law for Irish carriers to provide Advance Passenger Information (API) to the UK for passengers entering the UK from Ireland. From autumn 2017, the Irish immigration authorities will begin to automatically collect and analyse API data from carriers on inbound flights from outside the EU. An API data processing unit will be established, including personnel from INIS and An Garda Síochána. The API data will be collected, run against relevant watch lists, analysed and subsequent instructions sent to the relevant ports of entry. As of October 2017, the technical solution to process API was expected to be installed shortly and INIS indicated that API will then start to be collected on certain routes initially on a trial basis. ${ }^{131}$ Additionally, INIS indicated that, as required by the PNR Directive, a Director has been appointed to head up the Passenger Information Unit and has begun work to establish the Unit. ${ }^{132}$

As Ireland exercised its right to opt-in to the Dublin and Eurodac Regulations, this study examined data protection safeguards around data sharing and supervisory arrangements for the use of Eurodac. The Data Protection Commissioner is the national supervisory authority established pursuant to the 2013 Eurodac Regulation (Regulation (EU) 603/2013) for Ireland. 


\subsection{CHALLENGES}

Establishing identity is considered an issue within the framework for all migration procedures but is particularly challenging in the context of international protection applicants many of whom do not present with identification, and in returns procedures for failed asylum seekers (European Migration Network, 2013). In Ireland, the International Protection Office does not seek to establish identity; rather it is seen as part of the process of establishing the overall credibility of the applicant's claim.

Establishing identity is also commonly identified as challenging in the context of 'rejected asylum seekers' subject to a deportation order. In order to effect a deportation order the nationality of the person, if not the identity, must be established, often in the absence of identity documentation. The process of seeking documents for return is resource intensive.

Establishing identity in the context of visa applications is challenging where, for example, Ireland has no embassy; there are issues with the issuance, translation or validity of supporting or breeder documents; passports are not machinereadable but hand written, making them easier to forge; or when a country is moving from one form/style of identity documentation to another. ${ }^{133}$

INIS Registration Office noted that establishing identity is an issue/challenge in the context of residence permits for family, study, and remunerated activities, where the applicant has a non-machine readable/non-electronic passport and their passport therefore cannot be checked instantaneously against Interpol's Lost and Stolen Passport database via GNIB. 


\section{ANNEX A}

Judgment from the Court of Appeal was delivered in BS and RS v. the Refugee Appeals Tribunal on 14 June 2017. ${ }^{134}$ This case concerned two Albanian asylum seekers who contested the decision of the Refugee Appeals Tribunal upholding the decision of the Office of the Refugee Applications Commissioner that the United Kingdom was the Member State responsible for determining their applications for asylum. The applicants claimed asylum in Ireland on 16 December 2014, and completed their asylum application questionnaires on 26 December 2014. An information request by the Office of the Refugee Applications Commissioner to the United Kingdom, under Article 34 of the Dublin III Regulation, found that persons whose fingerprints matched those of the applicants (although under different names), had held a valid UK visa for the period 23 October 2014 to 23 April 2015 in contradiction to information given by the applicants in their asylum application questionnaires. ORAC found, pursuant to Article 12.2 of the Regulation, that the UK was the state responsible for examining the applications, as the applicants were in possession of valid UK visas.

This decision was upheld by the Refugee Appeals Tribunal and the applicants sought judicial review of that decision on the basis that the request from the Office of the Refugee Applications Commissioner to the United Kingdom under Article 34 of the Dublin III Regulation on the Annex $V$ request form was unlawful because the request form did not comply with Article 34 by reason of the failure to set out the grounds upon which the request was being made, and the failure to state the evidence on which the request was based. ${ }^{135}$ The applicants argued that this unlawful request to the UK resulted in transmission of personal information about them in the reply from the UK, in breach of the principle of preventing unauthorised disclosure under the Data Protection Directive 95/46/EC. The applicants also argued that the unlawful request was a breach of their right to protection of privacy under Article 8 of the EU Charter of Fundamental Rights and Article 8 ECHR. ${ }^{136}$ They submitted that such data unlawfully obtained should be erased in accordance with Article 34(9) of the Dublin III Regulation and excluded from consideration. ${ }^{137}$

The respondents accepted that the Annex $\mathrm{V}$ form was not completed in strict compliance with the Regulation, in particular that it failed to identify that the information was being sought for the purpose of establishing the Member State

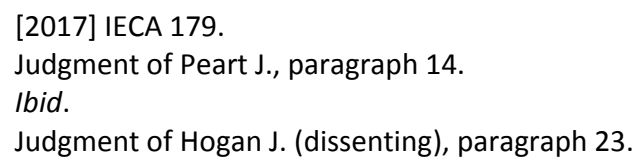


responsible for determining the applicants' asylum applications, but argued that in substance the request was a valid request and also that any 'frailty' in how the form was completed did not give rise to a right of challenge by the individual who was the subject of the request.

The High Court (Humphreys J.) found against the applicants on all the grounds put forward. ${ }^{138}$ The applicants subsequently appealed the decision to the Court of Appeal.

The three-judge Court of Appeal found against the applicants in a majority 2-1 decision. The judgment was largely based on a consideration of the scope of the effective remedy provisions in the Dublin III Regulation, and the applicants' argument that individually enforceable rights existed in relation to Article 34 requests (which are part of the administrative co-operation measures of the Regulation). The judgment placed emphasis on the CJEU judgment in Case C$63 / 15$ Ghezelbash, which found that

an asylum seeker is entitled to plead [.....] the incorrect application of one of the criteria for determining responsibility laid down in Chapter III of the Regulation. ${ }^{139}$

The Court of Appeal in BS and RS found that it was certain that the Dublin III Regulation:

introduced and enhanced the rights of individual asylum seekers in relation to the making of transfer decisions under the Regulation. ${ }^{140}$

However, the Court found that the concept of an effective remedy under Article 27(1) of the Dublin III Regulation could not be extended to the point that it could be used to challenge a transfer decision on the basis that the Annex $V$ form was incorrectly completed:

Where an applicant has an entitlement to an effective remedy, what is envisaged is a remedy to provide him with, or otherwise protect and vindicate some right or entitlement of which he has been wrongfully deprived or denied. It does not extend to a right to rummage around in the undergrowth of paper which has been generated during the asylum process, including the determination of the correct member state responsible under the Regulation, to see if some ' $T$ ' has not been crossed or some ' $I$ ' has not been dotted, and then cry foul when some infelicity is 
discovered which has no bearing upon any individual right or entitlement of the applicant which the effective remedy is there to protect. ${ }^{141}$

With regard to the data protection issues raised by the applicants, the Court of Appeal noted that the applicants' fingerprints were lawfully taken by the Irish authorities under section 9A of the Refugee Act 1996. The Irish authorities furnished these fingerprints to the UK authorities, who replied that they matched fingerprints held on their records. The Court of Appeal found that the provision of the fingerprints by the Irish authorities to the UK was in pursuit of the legitimate interest of providing information to ascertain which Member State was responsible for the applicants' applications, in accordance with section $2 \mathrm{~A}$ of the Data Protection Act 1988.

The Court also commented that had the personal data (i.e. the fingerprints) been erroneous in some way, a remedy was available in the Regulation for the applicants to request the data to be erased or amended.

The applicants had also argued that both the request and the UK's response to it breached the obligation under the Data Protection Directive (95/46/EC) to avoid unlawful or unauthorised access or disclosure. The applicants argued that the information furnished by the UK in response was provided in breach of Article 34 because there was no evidence that the information gathered by the UK came from a Eurodac enquiry. The Court of Appeal found, however, that the UK did not provide fingerprints in response to the request it received from ORAC, but rather simply confirmed that the lawfully obtained fingerprints which had been submitted to the UK authorities matched fingerprints on their own records. Therefore the UK could not have provided fingerprints in breach of Article 34 they simply did not transmit any fingerprints in their reply at all. ${ }^{142}$

There was one dissenting judgment. The dissenting judgment considered that there was insufficient clarity about, in particular, the scope of Articles 34(4) and 34(9) of the Regulation to resolve the issues in the case without making an Article 267 reference to the Court of Justice of the European Union. The dissenting judge considered that the question of whether Article 34(4) gives rise to individually enforceable legal rights remained open. The dissenting judge also did not consider it was clear, even if the requirements of Article 34 (4) were not met, whether or not Article 34(9) could be invoked to erase otherwise accurate information obtained from the UK authorities. 



\section{REFERENCES}

CASE LAW:

$B S$ and RS v. the Refugee Appeals Tribunal and others [2017] IECA 179

CJEU, Case C-34/09 - Gerardo Ruiz Zambrano v. Office National de l'Emploi

\section{LEGISLATION:}

Council Decision of 28 February 2002 concerning Ireland's request to take part in some of the provisions of the Schengen acquis (2002/192/EC).

Council Directive 2004/82/EC of 29 April 2004 on the obligation of carriers to communicate passenger data.

Data Protection Act 1988, as amended.

Directive (EU) 2016/681 of the European Parliament and of the Council of 27 April 2016 on the use of passenger name record (PNR) data for the prevention, detection, investigation and prosecution of terrorist offences and serious crime.

European Communities (Communication of Passenger Data) Regulations 2011.

Immigration Act 1999.

Immigration Act 2004.

International Protection Act 2015.

Regulation (EU) 604/2013 of the European Parliament and of the Council of 26 June 2013 establishing the criteria and mechanisms for determining the Member State responsible for examining an application for international protection lodged in one of the Member States by a third-country national or a stateless person (recast).

Regulation (EC) 767/2008 of the European Parliament and of the Council of 9 July 2008 concerning the Visa Information System (VIS) and the exchange of data between Member States on short-stay visas (VIS Regulation).

Regulation (EU) 2016/399 of the European Parliament and of the Council of 9 March 2016 on a Union Code on the rules governing the movement of persons across borders (Schengen Borders Code) (codification).

Regulation (EU) 603/2013 of the European Parliament and of the Council of 26 June 2013 on the establishment of - Eurodac - for the comparison of fingerprints for the effective application of Regulation (EU) No 604/2013 establishing the criteria and mechanisms for determining the Member State responsible for examining an application for international protection lodged in one of the Member States by a third-country national or a stateless person and on requests for the comparison with Eurodac data by Member States' law enforcement authorities and Europol for law enforcement purposes, and amending Regulation (EU) No 1077/2011 establishing a European Agency for 
the operational management of large-scale IT systems in the area of freedom, security and justice (recast).

S.I. No. 313/2013 - Data Protection Act 1988 (Section 2A) Regulations 2013.

S.I. No. 447/2003 - Immigration Act 2003 (Carrier Liability) Regulations 2003.

\section{LITERATURE:}

Arnold, S. and E. Quinn (2017). Family Reunification of Non-EU Nationals in Ireland, European Migration Network, Research Series No. 62, Dublin: The Economic and Social Research Institute.

Article 29 Data Protection Working Party (2013). Opinion 05/2013 on Smart Borders, Brussels: European Commission.

Barrett, A., F. McGinnity and E. Quinn (eds.) (2017). Monitoring Report on Integration 2016. Dublin: Economic and Social Research Institute.

Brady, T. (2012, 21 May). 'Two-thirds of failed asylum seekers had used false identities', Irish Independent, www.independent.ie.

Brady, T. (2015, 24 May). 'Young Pakistani men flee UK and flood into Ireland', The Sunday Independent, www.independent.ie.

Brady, T. (2016, 21 December). 'New passport data checks to combat jihadi terror threat', Irish Independent, www.independent.ie.

Data Protection Commissioner (2017). Annual Report 2016, Portarlington, Co. Laois: Data Protection Commissioner.

Department of Jobs, Enterprise and Innovation (2016). User Guide for Employment Permits Online System, Dublin: Department of Jobs, Enterprise and Innovation.

Department of Justice and Equality (2015). Press Release: Immigration in Ireland - 2014, Dublin: Department of Justice and Equality, www.justice.ie.

Department of Justice and Equality (2016a). Annual Report 2015, Dublin: Department of Justice and Equality.

Department of Justice and Equality (2016b). Irish Naturalisation and Immigration Service Immigration in Ireland: Annual Review 2016, Dublin: Department of Justice and Equality.

Department of Justice and Equality (2017a). Irish Naturalisation and Immigration Service Immigration in Ireland: Annual Review 2016, Dublin: Department of Justice and Equality.

Department of Justice and Equality (2017b, 9 June). Press release: Tánaiste Fitzgerald discusses counter terrorism measures with EU Justice Ministers in Luxembourg, www.justice.ie.

Department of Justice and Equality (2017c, 25 January). Press Release: Topical issues debate, www.inis.gov.ie. 
Eurodac Supervision Coordination Group (2016). Activity Report 2014-2015, Brussels: Secretariat of the Eurodac Supervision Coordination Group.

European Commission (2015a). The European Agenda on Security, Strasbourg: European Commission, http://ec.europa.eu.

European Commission (2015b). The European Agenda on Migration, Brussels: European Commission, http://ec.europa.eu.

European Commission (2015c). Return Handbook, Brussels: European Commission, http://ec.europa.eu.

European Commission (2016). Stronger and Smarter Information Systems for Borders and Security, Brussels: European Commission, www.eulisa.europa.eu.

European Commission (2017). Seventh progress report towards an effective and genuine Security Union, Brussels: European Commission, http://ec.europa.eu.

European Data Protection Supervisor (2017). Annual Report 2016, Luxembourg: Publications Office of the European Union.

European Migration Network (2013). Establishing Identity for International Protection: Challenges and Practices: EMN Synthesis Report, Brussels: European Migration Network.

European Migration Network (2014). Asylum and Migration Glossary 3.0, Brussels: European Migration Network.

European Migration Network (2014). Good Practices in the return and reintegration of irregular migrants: Member States' entry bans policy and use of readmission agreements between Member States and third countries, Brussels: European Migration Network.

European Migration Network (2017). Challenges and practices for establishing applicants' identity in the migration process, Brussels: European Migration Network.

Griffin, D. (2017, 23 January). 'Aer Lingus staff arrested over alleged immigrant smuggling'. The Irish Times, www.irishtimes.com.

Immigrant Council of Ireland (2016). Child Migration Matters: Children and Young People's Experiences of Migration, Dublin: Immigrant Council of Ireland.

Irish Naturalisation and Immigration Service (2016). Policy Document on Non-EEA Family Reunification, Dublin: Department of Justice and Equality.

Irish Naturalisation and Immigration Service (2017, 27 January). Press release: Tánaiste meets EU colleagues in Valetta for talks on counter-terrorism, migration and shared information systems, inis.gov.ie.

Irish Refugee Council (2012). Difficult to Believe: The assessment of asylum claims in Ireland, Dublin: Irish Refugee Council.

Irish Refugee Council (2015). Recommendations on the International Protection Bill 2015, Dublin: Irish Refugee Council.

Irish Refugee Council (2017). Submission to the United Nations Committee against Torture on the examination of Ireland's Report, Dublin: Irish Refugee Council. 
Joyce, C. (2013). Establishing Identity for International Protection: Ireland, European Migration Network, Dublin: The Economic and Social Research Institute.

Kane, J. (2016). 'Credibility Findings as a Basis for Judicial Review of Asylum Decisions', Irish Law Times, Vol. 34, No. 17, pp. 246-252.

Lally, C. (2017, 07 June). 'Men linked to killer questioned in Wexford and Limerick', The Irish Times, www.irishtimes.com.

O'Driscoll, S., D. Brown, N. Johnston and D. Gardham (2017, 06 June). 'Knifeman used a false name to leave Dublin for London', The Times [Irish edition], www.thetimes.co.uk.

Office of the Refugee Applications Commissioner (2011). Annual Report 2010, Dublin: Office of the Refugee Applications Commissioner.

Office of the Refugee Applications Commissioner (2012). Annual Report 2011, Dublin: Office of the Refugee Applications Commissioner.

Office of the Refugee Applications Commissioner (2013). Annual Report 2012, Dublin: Office of the Refugee Applications Commissioner.

Office of the Refugee Applications Commissioner (2015). Annual Report 2014, Dublin: Office of the Refugee Applications Commissioner.

Phelan, S. (2017a, 21 March). 'Terrorist plotting carnage in Europe duped authorities to secure move here', Irish Independent, www.independent.ie.

Phelan, S. (2017b, 24 March). 'Out of prison: Islamic terrorist freed today but deportation remains in doubt', Irish Independent, www.independent.ie.

Phelan S. (2017c, 25 March). 'Al-Qa'ida supporter who financed terror network faces deportation', Irish Independent, www.independent.ie.

Primetime (2017, 1 June). 'Mr. X' RTÉ, www.rte.ie.

Quinn, E. (2009). Programmes and Strategies in Ireland Fostering Assisted Return to Third Countries, European Migration Network, Dublin: Economic and Social Research Institute.

Quinn, E. (2011). Visa Policy as Migration Channel: Ireland, European Migration Network, Dublin: The Economic and Social Research Institute.

Quinn, E. and E. Gusciute (2015). Strategies Used to Support Return Policy in Ireland, European Migration Network, Research Series 42, Dublin: The Economic and Social Research Institute.

Quinn, E., C. Joyce and E. Gusciute (2014). Policies and Practices on Unaccompanied Minors in Ireland, European Migration Network, Dublin: The Economic and Social Research Institute.

Separated Children in Europe Programme (2016). Summer 2016 Newsletter, Leiden: Defence for Children - The Netherlands.

Sheehan, M. (2017, 11 June). 'Gardaí probe claim terrorist visited Ireland', Sunday Independent, www.independent.ie. 
Sheridan, A. (2017). Returning Rejected Asylum Seekers: Practices and challenges in Ireland, European Migration Network, Research Series 65, Dublin: The Economic and Social Research Institute.

UNHCR (2013). Burden of Proof: Credibility Assessment in EU Asylum Systems, Brussels: UNHCR.

Woulfe, J. (2017, 07 June). 'Chef in Limerick bought PPS number of terrorist on the black market', The Irish Examiner, www.irishexaminer.com. 
EMN Ireland,

Economic and Social

Research Institute,

Whitaker Square,

Sir John Rogerson's Quay,

Dublin 2, Ireland

Telephone +353 18632000

Email emn.ireland@esri.ie

Web www.emn.ie / www.esri.ie

Twitter @ESRIDublin 